\title{
Which STEM Majors Enroll in Online Courses, and Why Should We Care? The Impact of Ethnicity, Gender, and Non-traditional Student Characteristics
}

Claire Wladis

Borough of Manhattan Community College at the City University of New York, Mathematics

Dept., 199 Chambers St., New York, NY 10007, cwladis@ bmcc.cuny.edu

The Graduate Center at the City University of New York, Urban Education, 365 Fifth Avenue,

New York, NY 10016

Alyse C. Hachey

Borough of Manhattan Community College at the City University of New York, Teacher

Education Dept., 199 Chambers St., New York, NY 10007, hachey@tc.edu

Katherine Conway

Borough of Manhattan Community College at the City University of New York, Business Dept.,

245 Greenwich St., New York, NY 10007, kconway@bmcc.cuny.edu

Corresponding author: Claire Wladis, cwladis@ gmail.com, 917-267-7578 


\title{
Which STEM Majors Enroll in Online Courses, and Why Should We Care? The Impact of Ethnicity, Gender, and Non-traditional Student Characteristics
}

\begin{abstract}
Using data from roughly 27,800 undergraduate STEM (science, technology, engineering and mathematics) majors in the National Postsecondary Student Aid Study (NPSAS), this research examines the relationship between race/ethnicity, gender and non-traditional student characteristics and online course enrollment. Hispanic and Black STEM majors were significantly less likely, and female STEM majors significantly more likely, to take online courses even when academic preparation, socioeconomic status (SES), citizenship and Englishas-second-language (ESL) status were controlled. Furthermore, non-traditional student characteristics strongly increased the likelihood of enrolling in an online course, more so than any other characteristic, with online enrollment probability increasing steeply as the number of non-traditional factors increased. The impact of non-traditional factors on online enrollment was significantly stronger for STEM than non-STEM majors.
\end{abstract}

KEYWORDS: Online learning; Ethnicity; Gender; Non-traditional students 


\section{INTRODUCTION}

Enrollments in online courses are growing more rapidly than college enrollments overall, with between $30-60 \%$ of all current college students taking at least one online course during their academic career (Allen \& Seaman, 2010, 2013; Pearson, 2011). However, research on small samples has suggested that minority groups may not be enrolling in online courses at the same rate as White students (Angiello, 2002; Halsne \& Gatta 2002; Kaupp, 2013) and in particular, minorities may not be enrolling in STEM (Science, Technology, Engineering, Mathematics) online courses (AUTHORS, 2011; 2012). While Black, Hispanic, and American Indian/Alaska Native students are all less underrepresented in graduate STEM programs (see e.g. Anderson \& Kim, 2006; National Science Board, 2008), they also seem to be less likely to enroll in online courses (see e.g. Angiello, 2002; AUTHORS, 2012b), suggesting that the representation of nonwhite minorities in online STEM courses is likely even worse than in the same classes offered face-to-face. Thus, as online courses make up an escalating proportion of the STEM courses offered at colleges, there will likely be a particularly pressing need for extra resources in online STEM courses to increase the representation of non-white minorities in these courses, and to support their successful completion of these courses online.

Women are also underrepresented in STEM undergraduate programs, despite higher enrollment and persistence for women in higher education generally (see e.g. Chee, 2005; AUTHORS, 2009). However, in contrast to patterns observed with racial and ethnic minorities, women seem to enroll in online courses at higher rates than men (see e.g. Jaggars \& Xu, 2010; Shea \& Bidjerano, 2014; Xu \& Jaggars, 2011), and one study has shown that women were represented at significantly higher rates in online STEM courses compared to the same course offered face-to-face (AUTHORS, 2012a). This suggests that online courses may be an important entry point for female students in STEM disciplines.

Tentative evidence suggests that non-traditional student characteristics (Delayed enrollment; No high school diploma; Part-time enrollment; Financially independent; Have dependents; Single parent status; and Working full-time while enrolled) may be correlated with online course enrollment (Pontes, Hasit, Pontes, Lewis, \& Siefring, 2010) and further, that nontraditional students are more likely to be female and non-White (NCES, 1996, 2002). Thus, nontraditional characteristics may serve as a mediating variable for differences in online enrollment by gender and ethnicity, although this has never been empirically tested. Academic preparation, 
socioeconomic status (SES), English-as-a-second-language (ESL) status, and immigrant status are also potential mediating variables between ethnicity/gender and online enrollment, but evidence of these relationships in the research literature thus far is sparse and often conflicting.

As online learning makes up an increasing proportion of higher education instruction, enrollment and attrition in these courses will likely have a mounting impact on STEM degree attainment, and so it is essential that we better understand the factors that impact online STEM enrollment and course completion. However, well-controlled studies on online versus face-toface courses in STEM disciplines are quite sparse in the research literature. Randomly assigning large numbers of students to online versus face-to-face courses is impractical, thus requiring large-scale studies to contend with the challenge of controlling for differences in characteristics among those who enroll in courses online versus those that do not. Student characteristics vary significantly between STEM Majors who take courses online and those who take only face-toface courses, but have yet to be examined using a nationally representative dataset. If some characteristics more common among online students are also known to affect course outcomes, then these characteristics must be clearly identified and controlled in any future studies of online versus face-to-face course outcomes. This research advances previous studies by utilizing largescale national data to analyze if all STEM majors, regardless of ethnicity or gender, are proportionally represented in the online environment, and if not, to what extent differences in enrollment can be explained by non-traditional student characteristics, academic preparation, SES, ESL or immigration status. The results of this study are essential for future studies comparing online and face-to-face course outcomes in STEM, and more importantly to identify underrepresented groups of students in the online STEM environment so that policy makers and institutional decision makers can identify appropriate remedies and fill the demand for a diverse STEM workforce.

\section{Research Questions}

This paper explores the extent to which ethnicity, gender, and non-traditional student factors relate to online course enrollment, in particular for STEM majors. The specific research questions are:

1. Are there differences in the way that factors such as ethnicity, gender, and non-traditional risk characteristics predict online course enrollment for STEM versus non-STEM majors? 
2. Which student- and institutional-level factors are the strongest predictors of online enrollment for STEM majors specifically? In particular, do all ethnic/gender groups of STEM majors enroll in online courses at similar rates, either generally or when controlling for other potential mediating variables? Are non-traditional STEM majors more likely to enroll online, even when other potential mediating factors are controlled?

3. Which non-traditional characteristics are the most significant predictors of online enrollment for STEM majors?

\section{LITERATURE REVIEW}

\section{The U.S. and STEM Graduates}

The future of the U.S. economy depends on its role as a world leader in the STEM enterprise, which in turn, depends on the U.S.'s ability to internally produce an educated STEM workforce (George, Neale, Van Horne \& Malcom, 2001). Currently, there are double the number of science and technology job openings in the U.S. in comparison to workers ready to fill those jobs (Obama, 2012); half of all U.S. economic growth is ascribed to STEM fields, yet fewer than 5\% of U.S. workers are currently employed in the STEM sector (Babco, 2004; National Science Foundation, 2005). In the last few decades of the twentieth century, STEM jobs (outside of academia) increased by $159 \%$ and the trend in this century continues (Lufkin, 2008; Terrell, 2007).

Today, demand for educated STEM workers in the U.S. is being filled from abroad. More than $15 \%$ of scientists and engineers in the U.S. are immigrants, often adults, who earned their degrees abroad (National Science Foundation, 2011). Foreign workers account for more than $26 \%$ of occupations in science and engineering, a talent supply at risk as other nations take steps to increase their own STEM productivity and begin to challenge U.S. STEM leadership (George, Neale, Van Horne \& Malcom, 2001; National Science Board, 2008). Unless there is a drastic increase in STEM graduates in the U.S., the potential loss of foreign workers and the predicted increases in STEM-related jobs is apt to severely inhibit the U.S.'s ability to compete in the global market.

\section{The Changing Higher Education Landscape}

Advances in technology, coupled with the current post-secondary infrastructure's struggle to accommodate recent enrollment surges, is serving as a catalyst for evolution in higher education (Howell, Williams \& Lindsay, 2011; Layne, Boston \& Ice, 2013). Today, most 
colleges and universities in the U.S. are offering online courses for credit in core subjects (Downes, 2005; Parsad, Lewis \& Tice, 2008). In the last decade, the percentage of students taking online courses has more than tripled, with a third of all students attending college today, and over $60 \%$ of students attending community colleges, taking at least one online course during their academic career (Allen \& Seaman, 2010, 2013; Pearson, 2011). Recent data indicates that since 2010, online enrollments have risen by as much as 29\% (CCRC, 2013).

This move to online learning is expected to continue (Allen \& Seaman, 2013). As online learning is established as a basic part of the post-secondary experience, enrollment and success in the online environment will increasingly have an effect on STEM graduation rates. Therefore, in order for instructors, administrators, and policymakers to improve both access to and outcomes in higher education, both overall and more specifically for STEM majors, it is important to identify possible online student characteristics which may affect differences in enrollment and outcomes.

\section{Females, Minorities and Non-traditional college students, both in STEM and online}

Female Students Women and minorities are underrepresented in STEM undergraduate programs, despite higher enrollment and persistence for women in higher education generally (see e.g. Chee, 2005; AUTHORS, 2009; Freeman, 2004; George, Neale, Van Horne \& Malcom, 2001; Kim \& Sedlacek, 1996; Voorhees \& Zhou, 2000). Even when they do major in STEM, women are still less likely to work in a STEM field, holding less than $25 \%$ of STEM jobs (U.S. Department of Commerce, 2011).

Numerous profiles of online learners (not specific to STEM), have found they are more likely to be female (Dutton, Dutton \& Perry, 2002; Guri-Rosenblit, 1999; Halsne \& Gatta, 2002; Jaggars \& Xu, 2010; Moore \& Kearsley, 2005; Qureshi, Morton \& Antosz, 2002; Shea \& Bidjerano, 2014; Xu \& Jaggars, 2011), and our prior research found that female community college students enroll in significantly disproportionately more online STEM courses than males when compared to face-to-face STEM enrollments (AUTHORS, 2012a). Given that females are underrepresented in STEM and yet may be more drawn to online learning, online courses might provide an important point of entry for female students in STEM disciplines.

Minority Students Recent data suggest that Black, Hispanic, and American Indian/Alaska Native students are now choosing STEM fields at the same rate as White students and thus, enrollments have begun to equalize (National Science Board, 2008). However, because they are 
still less likely than their White peers to persist in STEM majors, minority students continue to be underrepresented in graduate STEM programs (11\%) in comparison to their proportion in the undergraduate college population (30\%) (Anderson \& Kim, 2006; Huang, Taddese \& Walter, 2000; National Science Board, 2008). Older, independent, Black or Hispanic students have been shown to be less likely to attain a STEM bachelor's degree and also more likely to drop out without graduating than White Students (U.S. Department of Education, 2009). This underrepresentation of minority STEM graduates is occurring at a time when most of the future growth in U.S. college enrollments is projected to come from minority student groups (National Science Board, 2008). Hence, if the U.S. is to produce the needed STEM educated workforce, then the gap between White and minority STEM retention rates at the undergraduate level must be examined and addressed.

While some studies assert that ethnicity is not a factor in online learning (Aragon \& Johnson, 2008), other research suggests that minorities may not fare as well in the online environment in comparison to their face-to-face and White student peers. Jaggars and Xu (2013) found that Black students had poorer performance (i.e. lower grades, higher withdrawal) in comparison to White Students in online courses. Shea \& Bidjenaro (2014) found that the odds of taking an online course was lower for Black students in comparison to White Students. Similarly, in a study using data from a New Jersey community college (Angiello, 2002), Hispanic students were less likely to enroll in online courses, and the gap between Hispanic online and face-to-face course passing rates was larger than for White students (although it was not analyzed for statistical significance). In line with these findings, we found that Hispanic and Black students in the Northeastern U.S., and in New York state specifically, were significantly less likely to enroll in online STEM courses versus White students, even when controlling for non-traditional student risk factors, academic preparation, socio-economic status, and ESL/immigrant status (AUTHORS, In Press [b]). In another study, we found that White community college students enroll in significantly more online STEM courses than other ethnic groups, a larger enrollment disparity than in face-to-face STEM classes (AUTHORS, 2012b). The evidence seems to be mounting for differences in enrollment and success based on ethnicity, however, few studies have rigorously controlled for potentially mediating variables, and all have used single school, single state or regional data and so national generalizability is still unknown. 
Non-Traditional Students Non-traditional student characteristics, as defined by the National Center for Educational Statistics, or NCES (1996, 2002), are: Delayed enrollment; No high school diploma; Part-time enrollment; Financially independent; Have dependents; Single parent status; and Working full-time while enrolled. Non-traditional student characteristics have long been associated with higher rates of college attrition (Bean \& Metzner, 1985; Rovai, 2002; NCES, 1995, 1996, 2002). Because these characteristics can impede college success and because online learning can provide greater flexibility in scheduling, which may be a critical factor for students with some of these characteristics (working, being responsible for dependents), the literature suggests that online students may be more likely to be "nontraditional" (Rovai, 2002). Tentative evidence suggests that non-traditional characteristics may be correlated with online course enrollment (Pontes, Hasit, Pontes, Lewis, \& Siefring, 2010) and further, that non-traditional students are more likely to be female and non-White (NCES, 1996, 2002). This implies that non-traditional characteristics may serve as a mediating variable for differences in online enrollment by gender and ethnicity, although this has yet to be empirically tested.

Profiles of online learners generally (not specific to STEM) contend that online learners are more likely to be any of the following: female, older, married and with other responsibilities (Dutton, Dutton \& Perry, 2002; Guri-Rosenblit, 1999; Halsne \& Gatta, 2002; Jaggars \& Xu, 2010; Long-Goding, 2006; Moore \& Kearsley, 2005; Qureshi, Morton \& Antosz, 2002; Shea \& Bidjerano, 2014; Xu \& Jaggars, 2011). Similar to what is found in traditional models of face-toface enrollment and retention, part-time attendance has also been suggested as affecting the enrollment and persistence of online students (Aragon \& Johnson, 2008; Dupin-Bryant, 2004; Moore, Bartkovich, Fetzner \& Ison, 2004; Morris, Wu \& Finnegan, 2005; Muse, 2003). It has been posited that students at risk of non-completion of their degree because of work and family commitments show a significantly greater preference for the flexibility and convenience of online courses (Pontes, Hasit, Pontes, Lewis \& Siefrig, 2010; Skopek \& Schuhmann, 2008). Some of the suggested online student characteristics have been shown to correlate with higher rates of persistence and success in higher education (e.g. female gender [Chee, 2005; AUTHORS, 2009; Freeman, 2004; Kim \& Sedlacek, 1996; Voorhees \& Zhou, 2000] or higher levels of academic preparation [e.g. Kurlaender \& Howell, 2012; NCES, 2005])) and some are 
correlated with lower rates (e.g. work and family obligations [Adelman, 2005, 2006; Astin, 1993; Bean \& Metzner, 1985; Tinto, 1993]).

Potential Mediating Variables The literature suggests other issues which may affect differences in higher education enrollments and/or outcomes for minority students (Lascher, 2008; Schneider, Martinez, \& Ownes, 2006). Academic preparation (as measured by G.P.A., Math SAT score and class rank), which has been shown to be significant in traditional models of faceto-face enrollment and retention (Allen, Robbins, Casillas \& Oh, 2008; DeBerard, Spielmans \& Julka, 2004), has also been found to be a potential mediating variable affecting online students (Aragon \& Johnson, 2008; Dupin-Bryant, 2004; Moore, Bartkovich, Fetzner \& Ison, 2004; Morris, Wu \& Finnegan, 2005; Muse, 2003). However, a recent study calls this into question (Shea \& Bidjerano, 2014), so questions still remain.

Socioeconomic status (e.g. Adjusted Gross Income (AGI)), whether a student receives financial aid benefits, whether the student receives federal benefits, parent's highest level of education) had been strongly linked with both ethnicity and higher education enrollment and outcomes generally (Allen, Robbins, Casillas \& Oh, 2008; Choy, 2001; Walpole, 2003), and therefore, is an important mediating variable when considering online course enrollment and ethnicity. Furthermore, some research has suggested that online students may be more likely to have applied for or received financial aid (Jaggars \& Xu, 2010; Shea \& Budjerano, 2014; Xu \& Jaggars, 2011).

ESL and immigrant status, have been suggested as potentially having a negative effect on online enrollment and success (Erisman \& Looney, 2007; Lopez, Gonzalez-Barrera, \& Patten, 2013; The New American Consumer, 2012). The rationale behind this is that minority and ESL students have been shown to possess fewer computer technical skills and to lag behind the national average in personal computer ownership and Internet usage (Fairlie, 2007; File, 2013; Rainie, 2010; Sankaran \& Sankaran, 2000), suggesting they may not be equally represented in the online environment. In addition, some research has shown that ESL students may prefer face-to-face interaction in a class in order to receive contextual and non-verbal cues (Erisman \& Looney, 2007). A few studies have found that online students tend to be native English speakers (Jaggars \& Xu, 2010; Xu \& Jaggars, 2011).

In addition to personal characteristics, institutional-level factors may be impacting online enrollment, both generally and in STEM. Although all types of higher education institutions 
have shown online enrollment growth rates, it has been suggested that online enrollment may differ by institution type. In particular, the research cites two-year associate institutions as having the highest online enrollment growth rates, while baccalaureate institutions have the fewest online enrollments and lowest growth rates (Allen \& Seaman, 2007). In total nearly half of all students at for-profit schools take online classes, while private non-profit institutions enroll $22 \%$ of their students in online classes, and public institutions enroll $24 \%$ of students in online classes (Allen \& Seaman, 2007; U.S. Department of Education, 2013). Non-selective two- and four-year institutions enroll 8.5 percent of their students fully online, compared to only 1.5 percent in highly selective institutions (Deming, Goldin, Katz \& Yuchtman, 2015). This may be important to consider as students who attend community colleges and work towards associate degrees are more likely to come from traditionally underrepresented groups with more disadvantaged backgrounds (Mooney \& Foley, 2011; U.S. Department of Education, 2009 \& 2011). Other research suggests that for first year students, enrollment in a private institution increases the likelihood of online enrollment and enrollment in a baccalaureate institution slightly reduces the chance of online enrollment in comparison to doctorate granting institutions (Chen, Lambert \& Guidry, 2010). The data also indicate that over 30\% of students at larger institutions ( $<20,000$ students) are enrolled in online classes versus $20 \%$ at smaller schools, with the fewest online students at schools with less than 1,000 students (U.S. Department of Education, 2013). Enrollment may also be impacted by geographic remoteness with larger proportions of students (36\%) enrolling in the Plains and southwest states, versus those who live in the more densely populated New England and mid-east states (15-18\%) (U.S. Department of Education, 2013). Thus, the literature suggests that controlling for institution-level factors is important in investigations of online enrollment patterns.

\section{Conceptual Framework}

This study's foundations are models of student retention for face-to-face students, including for baccalaureate students (Tinto, 1975, 1993, 1986) and community college students and adult learners (Bean \& Metzner, 1985). The few conceptual models of distance learner retention have not been widely tested and exclude important factors (Kember, 1989,1995; Rovai, 2003). This research is grounded in models of student retention and further studies that explored the role of ethnicity, gender, socio-economic status and financial aid as well as external factors such as work and family obligations on student success (Bean, 1990; Braxton, Bray, \& Berger, 
2000; Furr \& Elling, 2002; Ishitani \& DesJardins, 2002; Leppel, 2002; Paulsen \& St. John, 2002; Titus, 2006). All of these studies underscore how student characteristics play a role in shaping student success in college. While the numerous studies outlined above, and countless others, have examined student characteristics in relation to retention, this study expands on earlier research in two important ways: by focusing on online STEM students and by exploring nontraditional characteristics.

\section{PURPOSE OF THE STUDY}

Most of the research on demographic variables offers conflicting findings (Jones 2010). Moreover, previous studies have concentrated on just a few student characteristics and/or have utilized single institution or limited state/regional datasets (rather than analyzing nationally representative data), thus limiting generalizability. Further, the majority of the literature focuses on online learning generally, rather than seeking to spotlight STEM majors in the online environment specifically. Hence, it is still unclear how differing student characteristics interact with each other, and with gender and ethnicity, to affect online enrollment among STEM majors.

The purpose of this study is to determine to what extent STEM majors who take courses online are comparable to STEM majors who take only face-to-face courses in college, with a particular focus on ethnicity, gender, and non-traditional student characteristics. This study explicitly aims to determine if all genders and ethnic groups are proportionally represented among STEM majors in the online environment, and if they are not, to what extent differences in enrollment can be explained by other mediating variables such as non-traditional student characteristics (Delayed enrollment; No high school diploma; Part-time enrollment; Financially independent; Have dependents; Single parent status; Working full-time while enrolled), academic preparation (college and high school G.P.A., remedial courses ever taken, college credits earned in high school), socio-economic status (adjusted gross income (AGI), Pell recipient, TANF recipient, parents' highest education level), and ESL/citizenship status.

\section{METHOD}

\section{Data source and sample}

The data for this study are from the 2008 NPSAS dataset, a nationally-representative sample of institutions and students in higher education in the United States, collected roughly once every four years by the National Center for Education Statistics (NCES) at the U.S. Department of Education. The data come from multiple sources: Detailed data on student 
financial aid programs as well as educational outcomes are taken from institutional records. Data about family circumstances, demographics, education and work experiences, and student expectations are collected from students through a web-based interview that is conducted in both a self-administered mode and as a computer-assisted telephone interview. The 2008 dataset is the most recent of the currently available NPSAS datasets. NPSAS data includes hundreds of variables that include information about a student's academic progress and performance, their financial aid, their family and work situation, as well as numerous demographic characteristics. This study includes data from roughly 27,800 undergraduate STEM majors who participated in the NPSAS.

We note that while for the full NPSAS sample (including both STEM and non-STEM majors), $20.4 \%$ of students enrolled in at least one online course in $2007-2008$, only $17.6 \%$ of the STEM majors enrolled in an online course that year, which is significantly lower $(\alpha=0.001)$.

\section{Measures}

The focus of this study is on student characteristics that may correlate with online course enrollment for STEM majors, with a particular interest in ethnicity, gender, and non-traditional student characteristics. The dependent variable, online course enrollment, is operationalized by whether or not a student took at least one online course during the 2007-2008 school year as indicated in the NPSAS dataset. In limiting the sample to students who are STEM majors, we used the National Science Foundation's (NSF) definition of STEM and included math, computer, science, engineering, technology, and social and behavioral science majors. For a breakdown of different majors in the sample, see Table 1.

For the independent variables, in addition to gender, we used a measure of race/ethnicity that combines both race and Hispanic ethnicity into a single measure; students of mixed race/ethnicity were included in the "other" category because of relatively small numbers in the sample. For some analyses, we combined race and gender categories to get a better picture of what was happening with ethnicity/gender subgroups; for example, because Hispanic ethnicity decreased the likelihood of enrolling in an online course while female gender increased the likelihood, we felt it would be informative to look at Hispanic males and Hispanic females separately. We ran each model with both ethnicity and gender as separate categories and with ethnicity and gender combined into one larger category, and found that in each case, the model fit was slightly better with ethnicity and gender combined (using AIC measures - see Results 
section below for more details). Because of this, much of the data is reported with these two factors combined.

Because of preliminary evidence that non-traditional student characteristics may correlate with online enrollment and the significant evidence that they correlate with course and college outcomes, this study also uses NPSAS non-traditional student risk index . The risk index combines a number of factors (Delayed enrollment; No high school diploma; Part-time enrollment; Financially independent; Have dependents; Single parent status; Working full-time while enrolled) historically associated with non-traditional students and correlated with lower persistence and completion rates in college (DesJardins, Ahlburg, \& McCall, 1999; Murtaugh, Burns, \& Schuster, 1999; NCES, 1996, 2002; U.S. Department of Education, 1999). The risk index allows us to see how the number of non-traditional risk factors may influence the likelihood of online enrollment. Many observational studies that have aimed to control for selfselection into online courses often use only one or two non-traditional student characteristics (e.g. working full-time) as controls; however, if the likelihood of enrolling in an online course increases as the number of non-traditional risk factors increases, this suggests that selection into online courses cannot be adequately controlled if only one or two non-traditional student characteristics are included in the model.

However, to better understand which non-traditional student characteristics are most highly correlated with online course enrollment, we also include a number of models which incorporate these risk factors separately. In these models, we include each of the individual nontraditional student characteristics included in the risk index, separate characteristics which determine whether a student is financially independent and we also use a modified measure of whether a student has dependents, by including a variable which measures whether the student has at least one dependent child under the age of six years old.

Other factors included in this study were chosen because they are the factors most frequently posited in the literature as possible mediating variables for differences in higher education enrollments or outcomes for minorities, female students, and non-traditional students. These overall factors include academic preparation, modeled in this study using college and high school G.P.A., whether college credits were earned in high school, and whether the student ever took a remedial course (Aragon \& Johnson, 2008; Dupin-Bryant, 2004; Moore, Bartkovich, Fetzner \& Ison, 2004; Morris, Wu \& Finnegan, 2005; Muse, 2003); and SES, modeled in this 
study using AGI, whether the student was a Pell grant recipient, whether the student received federal benefits, and the parent's highest level of education (Contento, 1999; Walpole, 2003)). ESL and citizenship status were also added as possible mediating factors because these are both closely linked with ethnicity (Erisman \& Looney, 2007; Lopez, Gonzalez-Barrera, \& Patten, 2013), and since some anecdotal evidence has suggested that online courses may require more reading and writing, ESL status could be an important factor in the online environment. Institutional factors included the highest degree offered by the institution, enrollment size, the degree of urbanization, institution type (public, private for-profit, private not-for-profit), the level of institutional selectivity, and the percentage of minority enrollment.

The weight variable used in this analysis was WTA000, the final student weight or study weight, which was based on the full sample. Because this study did not use any Computer Assisted Telephone Interview (CATI) variables from the NPSAS dataset, this is the appropriate weight for the analyses done here.

\section{Data Analyses}

The analysis uses binary logistic regression, with online course enrollment as the binary dependent variable, and measures of ethnicity, gender, non-traditional student characteristics, academic preparation, SES, and ESL/citizenship status as the independent variables. First, separate models were run with each set of factors used to predict online enrollment, in order to assess overall online enrollment trends for each set of factors individually. Then, a comprehensive model was built including all six categories of independent variables, by adding a different category of independent variables at each step. For the sake of brevity, these models are not reported here, but some observations about potential mediating relationships, which were first suggested by this step-wise model construction, are discussed. Then we analyze specific non-traditional student risk factors, first looking at their individual predictive relationship with online enrollment by running separate individual models, and finally by replacing the nontraditional student risk factor index in the full model with specific non-traditional risk factors. Several different combinations of non-traditional risk factors were explored using these models, and the final full model with the best fit is reported here. We also describe the most parsimonious model. 


\section{RESULTS}

\section{Differences in online course enrollment for STEM versus non-STEM majors}

We started by exploring to what extent ethnicity, gender, and non-traditional risk factors predict online course enrollment for STEM versus non-STEM majors. A full model was run containing all of our predictor independent variables on the set of all STEM majors in the dataset, the set of all non-STEM majors in the dataset, and then finally we ran a model containing ethnicity, gender and the non-traditional risk factor index on the full dataset containing both STEM and non-STEM majors to determine if the interactions between these independent variables and a student's major (STEM vs. non-STEM) are significant. These results can be seen in Table 2, which shows that each additional non-traditional risk factor increased the likelihood of online enrollment for both STEM and non-STEM majors, but that the likelihood of online enrollment was increased significantly more for STEM majors than for nonSTEM majors. This suggests that while non-traditional student characteristics are important predictors of online enrollment for all majors, they may be particularly important predictors for STEM students.

\section{Differences in online enrollment by ethnicity and gender, for STEM majors}

We initially ran distinct binary logistic regression models with each category (ethnicity, gender, non-traditional risk factors, academic preparation, SES, ESL/citizenship) of factors tested separately, to determine the extent to which each category of factors is a significant predictor of online enrollment on its own (see Table 3). Then we ran a final full model containing all independent variables together, with ethnicity and gender as separate variables (Table 3) and with ethnicity and gender combined as a single variable (Table 6). A final model with ethnicity and gender combined into a single variable and with non-traditional student risk factors listed separately was also run (Table 8).

Individually (controlling for no other variables), ethnicity was a highly significant predictor of online enrollment for STEM majors, with Hispanic and Asian STEM majors significantly less likely to take courses online (Table 3). Gender was also a highly significant predictor of online enrollment on its own (when controlling for no other variables), with female STEM majors significantly more likely to take online courses (Table 3). In the full model (Tables 3 and 6), we see that even when academic preparation, socioeconomic status (SES), and other potential mediator variables such as citizenship and English-as-second-language (ESL) 
status are controlled, Hispanic $(\alpha=0.001)$ and Black $(\alpha=0.05)$ STEM majors are significantly less likely and female STEM majors $(\alpha=0.001)$ are significantly more likely to enroll in online courses. Both Black and Hispanic male STEM majors are significantly less likely to enroll online at the $\alpha=0.001$ level, and White and Asian male and Hispanic female STEM majors are significantly less likely to enroll online at the $\alpha=0.01$ level, in comparison to White STEM majors. These relationships do not change significantly when we exchange the non-traditional risk index for individual non-traditional risk factors (Table 8).

The full model (Table 3) was built in a step-wise fashion, adding each set of independent variables in a separate step (first ethnicity and gender; then non-traditional risk index; then academic preparation; then SES; then ESL/citizenship). The intermediate models are not reported here; however, a few patterns were observed which suggested that further tests for mediating relationships with ethnicity or gender should be undertaken. Specifically, changes to coefficients and significance levels suggested that non-traditional student characteristics may mediate the relationship between ethnicity/gender and online enrollment, and that and ESL or citizenship status may mediate the relationship between ethnicity and online enrollment.

However, unlike with ordinary linear regression (OLR), the degree of unobserved heterogeneity in the model will affect the magnitude of model coefficients (Mood, 2010). The addition of new variable(s) in a logistic regression model may account for some of the residual variability of the original model, and this may increase both the power of statistical tests and the magnitude of regression coefficients. However, it is also possible that added variables are partially correlated with variables in the original model, and therefore, that some or all of the change in coefficients is due to relationships between the added independent factors and the original ones. So in order to assess possible mediation in the model, we use the Sobel test. The Sobel test determines whether a second independent variable significantly mediates the relationship between one independent variable and the dependent variable, and is a valid technique for identifying mediation in large samples (Preacher \& Hayes, 2008).

\section{Do non-traditional characteristics mediate the relationship between ethnicity or gender and online enrollment for STEM majors?}

While overall Black STEM majors were more likely than White STEM majors to enroll online (although this difference was not statistically significant), after adding non-traditional 
student risk factors to the model, Black STEM majors become statistically significantly less likely to enroll online than Whites. Also, the strength of the following relationships increased: Black and Hispanic STEM majors were less likely and, female STEM majors were more likely to take an online course. In contrast, the strength of the relationship between Asian ethnicity and lower online enrollment decreased.

From Sobel statistics reported in Table 7, it is evident that the presence of at least one non-traditional risk factor mediates both ethnicity and gender in predicting online enrollment for STEM majors. In particular, this mediation is highly significant for Black, Hispanic and female STEM majors, and mildly significant for Asian STEM majors. Non-traditional characteristics only partially mediate the relationship between ethnicity/gender and online enrollment, since both ethnicity and gender remain significant predictors of online enrollment even after nontraditional characteristics are added to the model. Because Black and Hispanic STEM majors in this sample were more likely to have non-traditional risk factors, they were even more underrepresented online when compared to White STEM majors with the same number of nontraditional risk factors. In contrast, Asian and female STEM majors were slightly less likely to have non-traditional risk factors, and therefore when comparing Asian and White, or female and male, STEM majors with the same number of non-traditional student characteristics, their representation online actually increases.

We noted a reduction in the underrepresentation of all minorities when adding ESL and citizenship status to the model, suggesting that ESL or citizenship status may mediate the relationship between ethnicity and online enrollment; however, none of the Sobel's test statistics (for the sake of brevity, not reported here) were statistically significant at the $\alpha=0.10$ level.

\section{Non-traditional Student Characteristics}

\section{The Non-traditional Risk Index}

Over $76 \%$ of all STEM majors enrolled in online courses in this sample had at least one non-traditional risk factor, compared to only 55\% of STEM majors who did not enroll online. In all models, non-traditional student characteristics strongly increased the likelihood of a STEM major enrolling in an online course $(\alpha=0.001)$, with greater odds ratios than any other characteristic, and this relationship appears to increase as the number of risk factors increases. In fact, generating predicted probabilities based on the number of risk factors, using the model in Table 6 for the reference group, yields Figure 1. Apparent in this graph is that a STEM major 
with five or more non-traditional student characteristics is almost three times more likely than a STEM major with none of the characteristics to enroll in an online course, and a linear regression on these points suggests that each additional non-traditional student characteristic increases a STEM major's probability of enrolling online by roughly four percentage points on average. These trends are broken down by ethnicity/gender in Figure 2, where we can see how ethnicity, gender, and non-traditional student characteristics alone impact the odds of online enrollment: for example, the probability of a White female STEM major with five or more non-traditional student characteristics enrolling in an online course is about 25 percentage points higher, or almost 4.5 times higher than an Hispanic male STEM major with no non-traditional student characteristics.

\section{Individual Risk Factors}

So far this analysis has used the NCES Non-traditional Risk Index to assess nontraditional student characteristics, in order to illustrate the relationship between the number of non-traditional risk factors present and the increasing likelihood that a student will enroll online, especially since these factors are also associated with higher college dropout risk. However, the non-traditional risk index does not give clear insight into which specific non-traditional student factors are the strongest predictors of online enrollment for STEM majors, or about how these risk factors may relate to one another. We therefore further explore non-traditional student risk factors by investigating models which break down the index into individual risk factors. Specifically, the risk index includes the following seven factors: Delayed enrollment; No high school diploma; Part-time enrollment; Financially independent; Have dependents; Single parent status; Working full-time while enrolled. Financial independence is also itself an index of a number of different factors. Specifically, students are designated as financially independent if one of the following criteria is met: they are 24 or older; they are married; they have dependents; they are a veteran or on active duty; or they are an orphan or ward of the court.

We therefore investigated models including each of these specific risk factors individually (Table 8), and additionally explored a different operationalization of "having dependents". Having children is often cited as a likely reason for students to enroll online, because of the significant time needed for childcare and the appealing flexibility of the online medium. This would suggest that having younger children at home, particularly infants or preschoolers, would be a better predictor than simply having other dependents, such as children 
in high school or college. Furthermore, students with school-aged children or older are more likely to be 24 years old or older, and therefore limiting the "parent" variable to those students who have young children may eliminate some of the collinearity between age and "having dependents".

We explored models with a number of different combinations of non-traditional factors, including: 1) only those seven factors included in the risk index; 2) those risk factors included in the risk index except that financial independence was replaced with the individual factors from which it was generated; 3) both of these models were repeated with "children under 6" and again with "children under 2" used instead of "has dependents"; and finally 4) a parsimonious model was explored. AIC values suggest that the model with financial independence broken down, and "children under 2" used in place of dependents, had the best fit, and the details of this model are given in Table 8.

When considered individually, all seven of the non-traditional risk factors, the sub-factors which make up the financial independence category, and the two alternate operationalizations of dependent children (under 6 and under 2) are highly significant predictors of online enrollment for STEM majors. However, because some of these characteristics are highly correlated (e.g., by definition all students with dependents are financially independent, and all single parents have dependents), once multiple factors are included in the model simultaneously, the relative significance of various factors disappears. In the full model (Table 8), being active-duty military, 24 years of age or older, and working full-time were significant predictors of online enrollment for STEM majors at the $\alpha=0.001$ level, and being married, being enrolled part-time, and having a dependent child under 2 were also significant predictors of online enrollment (at the $\alpha=0.05$ level). Having a history of ever having taken a remedial course was also a highly significant predictor of online enrollment $(\alpha=0.001)$, which might also be viewed as another measure of non-traditional status.

The most parsimonious model was obtained through backwards elimination with a threshold of $\alpha=0.10$. For the sake of brevity, the coefficients for this model are not presented here, but the factors which remained in the most parsimonious model were: ethnicity/gender; part-time enrollment; having a dependent child under the age of 2; working full-time while enrolled; being 24 years old or over; being married; being active-duty military; and ever having taken a remedial course. No other measures of academic preparation (outside remedial course- 
taking), and no measures of SES, ESL status, or citizenship remained after backward elimination.

To illustrate the way in which these specific non-traditional characteristics relate to online enrollment for STEM majors, predicted probabilities for students in the reference groups with none of these characteristics, and then for students with increasing numbers of these characteristics are displayed in Figure 3. Each characteristic is added to the previous one, so that, for example, online enrollment rates were $14 \%$ for students with none of these characteristics, $23 \%$ for older students, and $31 \%$ for older students who worked full-time while enrolled. Students with all of the significant non-traditional characteristics enrolled online at a rate of $83 \%$, compared to only $14 \%$ for those with none. If we exclude active duty military status, this number is still quite high at $58 \%$.

\section{Other Predictors of Online Enrollment for STEM Majors}

From the models presented here, ethnicity/gender and non-traditional student characteristics are clearly the strongest predictors of whether or not a STEM major will enroll in an online course. Looking at each of the base models (Table 3) separately to observe the overall predictive power of other factors, we observe the following trends: Higher levels of current academic achievement, as measured by college G.P.A., were somewhat significantly but weakly correlated with higher online enrollment (at the $\alpha=0.10$ level); however, prior academic preparation, as measured by the need for remediation in college and high school achievement, seemed to be inversely correlated with online enrollment, with students with weaker prior academic preparation enrolling online at higher rates. STEM majors who had ever taken a remedial course, or who were missing high school G.P.A. (meaning that they were 30 or older and/or did not take the SAT or ACT) were highly significantly more likely to take an online course. In comparison to STEM majors with high school G.P.A.'s below 2.5, STEM majors with high school G.P.A.'s between 3.0-3.4 and with high school G.P.A.'s between 3.5-4.0 were significantly less likely to take an online course (in contrast to college G.P.A., as high school G.P.A. increased, odds ratios actually decreased, so that the probability of taking an online course went up as high school G.P.A. went down).

SES seemed to be inversely correlated with online enrollment, with lower-SES students enrolling online at higher rates. In the model containing only SES factors, Average Gross 
Income (AGI) was highly significantly negatively correlated with online enrollment ${ }^{1}$ for STEM majors, while STEM majors whose parents had a bachelor's degree or higher were significantly less likely to take an online course than those whose parents had earned a technical or associates degree or who had some college, with decreasing odds ratios for each increase in parental education, suggesting that odds of taking an online course increase as level of parental education goes down (when controlling for the other SES measures included in the model).

ESL and citizenship seem to be slightly relevant to online enrollment, but much less than the other factors studied here. While the overall model containing only ESL and citizenship status was mildly significant (at the $\alpha=0.10$ level), neither factor individually was significant in predicting online enrollment.

However, after controlling for ethnicity, gender, and non-traditional student characteristics, all of these factors lost their significant relationships to online enrollment for STEM majors. G.P.A., for example, has been cited in some studies as being higher for students who take courses online (e.g. Xu \& Jaggars, 2011), and the same as face-to-face in others (Authors, 2012). The pattern observed in this study may explain why: while higher college G.P.A.'s were positively correlated with online enrollment, this relationship disappeared once non-traditional student characteristics were controlled. Since student parents, like older students, are more likely to both have higher G.P.A.'s (NCES, 2009, 2012) and to enroll at higher rates online, age and/or having dependents may be mediating the relationship between college G.P.A. and online enrollment, which we confirmed using Sobel's test (Table 9). Because the relationship between G.P.A. and online enrollment was no longer significant once either age or having dependents was controlled, this mediation is complete, so that age or having dependents completely explains the significant relationship between college G.P.A. and online enrollment for STEM majors.

In terms of institutional-level factors (see Tables 4 and 5), the level of the highest degree offered by the institution was a significant predictor of online enrollment, with two-year colleges and colleges in the "special focus or other" enrolling significantly more students online than four-year colleges or doctoral universities. Master's degree institutions also enrolled

\footnotetext{
${ }^{1}$ Because the odds ratio for AGI is per dollar of income, rounding produces an odds ratio that looks like 1. However, the standardized coefficient (not displayed here for the sake of brevity) for this factor in this model was negative, showing a negative relationship between AGI and probability of online enrollment.
} 
significantly more students in online courses than four-year colleges or Ph.D.-granting institutions. Institutions that were not degree granting enrolled significantly fewer students in online courses than at four-year or doctoral institutions. Enrollment size was positively correlated with higher levels of online enrollment, and this relationship was strongly significant. Public institutions enrolled significantly more online students than private not-for-profit or forprofit institutions. However, students who attended more than one institution type were significantly more likely to enroll in online courses than students attending any single type of institution (public or private). And finally, as the selectivity of an institution went up, the proportion of STEM majors enrolled in online courses went down; this pattern was highly significant at all levels of selectivity.

After controlling for all institutional factors at once, there was no longer any significant difference in rates of online enrollment between two-year colleges and either four-year or doctoral institutions; however differences between both master's-degree-granting institutions and institutions that were not degree granting, in comparison to both four-year and doctoral institutions, remained. The relationships between enrollment size and selectivity and online enrollments also remained the same. The pattern of higher rates of online enrollment at public institutions in comparison to private ones remained but was weakened by controlling for all institutional variables at once. Students who attended more than one type of institution were still highly significantly more likely to enroll online than students who attended any single type of institution (public or private). And finally, while without controls the percentage of students enrolled who were white and non-Hispanic was not a significant predictor of online enrollment, after controlling for other institutional characteristics it became mildly positively significantly associated with higher rates of online enrollment.

After controlling for student-level characteristics as well as all institutional-level characteristics at once, the relationships between both enrollment size and selectivity remained the same, although were slightly less significant. Public institutions remained significantly more likely to enroll STEM majors than private ones (either not-for-profit or for-profit), or than nondegree granting institutions. And students who attended multiple institution types remained highly significantly more likely to enroll in online courses than students who attended any single type of public or private institution. 


\section{Multi-collinearity and Model Fit}

For all final full models displayed, variance inflation factors (VIF) were calculated, to rule out multi-collinearity, and almost all of them were between 1 and 2, with the highest value being 3.59. This is far below the standard threshold of 10 often cited in the literature as the point at which multi-collinearity may pose a serious problem in the proposed model (see O'Brien, 2007 for a review).

Comparing the log likelihood and $\mathrm{AIC}^{2}$ values for each set of five nested models used to create the full models displayed in Tables 3 and 6, the full model containing all five sets of factors displayed in these tables is the best fit in each case, even though ESL and citizenship status on their own are not individually statistically significant predictors of online enrollment. Comparing AICs from the full models in Table 3 (ethnicity and gender separate) and Table 6 (ethnicity and gender combined), the model combining ethnicity and gender into a single category, with each subgroup identified by both ethnicity and gender, is the model with the best fit, but we include the model where ethnicity and gender are separated because this gives a clearer picture of ethnicity-specific and gender-specific effects on average. Furthermore, comparing AICs across all full models with different operationalizations of non-traditional student characteristics shows that the full model with separate non-traditional student risk factors as listed in Table 8 has the best fit.

\section{DISCUSSION AND IMPLICATIONS}

\section{Differences in how ethnicity, gender, and non-traditional student characteristics predict online enrollment for STEM versus non-STEM majors}

Models incorporating ethnicity, gender, and non-traditional student characteristics to predict online enrollment produced significantly different results for STEM versus non-STEM majors. For both STEM and non-STEM majors, each additional non-traditional risk factor increased the likelihood of online enrollment, but the likelihood of online enrollment was increased significantly more for STEM majors than for non-STEM majors, suggesting that while

\footnotetext{
${ }^{2}$ AIC stands for Akaike information criterion, which is $2 k-2 L$ where $k$ is the number of parameters in the model and $L$ is the log of the likelihood function of the model. AIC not only reflects model fit, but also adjusts that fit by penalizing the model for additional parameters. The model with the lowest AIC has the best fit. However, models whose AIC is close to the lowest AIC value are often considered and sometimes chosen as the best model based on motivating theory and other factors (see for example Burnham \& Anderson, 2002, pg 70).

AIC can be used to compare both nested models (as is possible with log likelihood values only) and non-nested models (which is not possible with log likelihood values).
} 
non-traditional student characteristics are important predictors of online enrollment for all majors, they seem to be particularly important predictors for STEM students.

\section{Representation of minority and female STEM majors online}

Asian and Hispanic STEM majors were significantly less likely on average to enroll online than Whites, and women were significantly more likely to enroll online than men. Black STEM majors were on average just as likely to enroll in online courses as White students. However, after controlling for non-traditional risk factors, the relationship between ethnicity/gender and online enrollment shifts. Black STEM majors become significantly less likely to enroll online, Hispanics become even less likely and women even more likely to enroll online, and the significant relationship between Asian ethnicity and online enrollment almost disappears. Tests for mediation show that non-traditional student characteristics mediate the relationship between both ethnicity and gender. In particular, even though some minorities are clearly underrepresented in the online environment (e.g. Hispanic students), controlling for nontraditional student characteristics unmasks further underrepresentation that is not immediately apparent because different ethnic groups have different rates of non-traditional characteristics. Only after controlling for non-traditional student characteristics do we see that Black STEM majors are significantly underrepresented online, and that Hispanic STEM majors are even more underrepresented than they first appear. Black and Hispanic males seem to be particularly underrepresented, followed by Hispanic females. This is troubling because it suggests that students who are likely already at a disadvantage in STEM disciplines may be missing out on an educational experience that is viewed as critical in the job market, where the vast majority of employers conduct some form of training online and where technical skills are increasingly valued (e.g. Mossberger, Tolbert C. J., \& McNeal, 2007).

In contrast, female STEM majors are overrepresented in online courses, which suggests that the online environment may be one tool that could be used to create STEM classes with higher representations of female students, and possibly promote higher rates of STEM degree completion among women; this is a potential area for future research.

\section{Online courses and access to higher education: non-traditional students online}

STEM majors with non-traditional student characteristics were significantly more likely to enroll in online courses, even when ethnicity, gender, academic preparation, and SES were controlled. STEM majors who had ever taken a remedial course (which may also be considered 
a marker of non-traditional status) or who had attended multiple institution types (another potential marker of non-traditional status) were also significantly more likely to enroll online. And students enrolled at less selective institutions and public institutions (where there are higher proportions of non-traditional and disadvantaged students) were significantly more likely to enroll online. The greater the number of non-traditional characteristics that a student possessed, the more likely they were to enroll online. Specifically, STEM majors who were financially independent, who were 24 years of age or older, who had young children, who worked full-time while enrolled, who were married, who were active duty military, or who were enrolled part-time were all significantly more likely to enroll in online courses, even when other factors were controlled. This suggests that STEM majors who have traditionally been less likely to pursue higher education (and who are less likely to persist once they enroll) may be more likely to enroll in courses if they are offered online; another important area for future research. While this study can provide no proof that offering online courses increases access to higher education for these groups, the high enrollment rates of at-risk and non-traditional STEM majors in online courses suggests that the availability of online courses may impact the enrollment decisions of this group, and therefore, institutions should be cautious about taking actions which may limit access to online courses. While it is possible that when courses are not offered online students will simply take them face-to-face, it is likely that limiting or eliminating access to online courses could prompt some non-traditional and at-risk students to enroll in fewer classes each semester, or not to enroll in college at all. Because academic momentum is strongly associated with college completions rates (Attewell, Heil \& Reisel, 2012), limiting access to online courses more generally could negatively impact college persistence and completion, particularly for nontraditional students. This is supported by recent research by Shea \& Bidjerano (2014) who, using national data, report that early access to online courses can help with degree attainment. More research is clearly needed to determine how access to online courses may impact college persistence and completion, particularly for non-traditional and at-risk groups.

\section{Online STEM student characteristics and implications for online course outcomes}

While the high proportion of non-traditional STEM majors enrolled in online courses suggests that these courses potentially increase access for this group, a documented trend of higher attrition in online courses (Carr, 2000; Moody, 2004; Morris \& Finnegan, 2008-9; Norris, 2002; Patterson, \& McFadden, 2009; AUTHORS, In Press [a]) alternatively suggests, that taking 
online courses may impede some students' progress through college. One reason for the differences in online versus face-to-face attrition may precisely be the high numbers of students with non-traditional student risk factors enrolled in online courses, since these factors correlate with college dropout (NCES, 1996, 2002). Non-traditional students, students with weaker prior academic preparation, and students with lower SES were all more likely to enroll in online courses on average. All of these factors are significantly related to college dropout, suggesting that STEM students who choose to take courses online may already be particularly at risk for course and college dropout. The only factors associated with both online enrollment and improved college outcomes were: White ethnicity, female gender, and college G.P.A. However, while women may be more likely to persist in college, they are significantly less likely than men to persist in STEM degrees (see e.g. Chen \& Weko, 2009). The relationship between higher G.P.A. and higher rates of online enrollment disappeared after controlling for non-traditional student characteristics, and tests for mediation show that, for STEM majors, both age and having dependents mediate the relationship between G.P.A. and online enrollment, so that students parents and older students have higher G.P.A.'s on average and are also more likely to enroll online. However, both students with children and older students are also significantly less likely to persist and to obtain degrees despite their higher G.P.A.'s (see e.g. NCES, 2009; Shapiro et al., 2013).

Future observational studies which aim to analyze the differences between online and face-to-face course outcomes for STEM majors will need to use statistical techniques to control for the student characteristics identified in this study as significant predictors of online course enrollment. Some of the best studies conducted to date on this topic have used only a few of the non-traditional student characteristics which were shown to be significant predictors of online enrollment in this study, and many other studies have used none. For example, Jaggars \& Xu (2010; Xu \& Jaggars, 2011) have conducted some of the most rigorous research to date on outcomes in online versus face-to-face courses; however, one of their most recent studies (Xu \& Jaggars; 2011) controlled for age, delayed enrollment, and part-time enrollment (and financial independence, in a smaller subsample); however, this study did not include full-time work, military status, or whether the student was married or had children, which are factors that remained significant in predicting online course enrollment even after controlling for other nontraditional risk factors. In any future observational studies on online-versus-face-to-face course 
outcomes that hope to rigorously control for the self-selection of STEM majors into online courses, it will be essential to include all of these non-traditional factors.

\section{Limitations}

This study only looks at the probability that a STEM major took an online course; because of the limitations of the dataset, it was not possible to draw conclusions about the number or the specific courses taken online, which may have revealed different relationships between online enrollment and the independent variables. Some of the subgroups of interest in this study were relatively small (e.g. students who were active duty military, TANF recipients), and therefore, it was not always possible to draw firm conclusions about every group; repeated studies using larger samples sizes could be helpful in clarifying these results. Finally, while we accounted for many significant factors in this study, we acknowledge that there may be additional factors which could only be tested by more qualitative means (e.g. motivation, technology or self-directed learning skills) which could also contribute to online enrollment choices among STEM majors; such factors may shed additional light on STEM major online enrollment but are beyond the scope of the data and type of analyses conducted in this work.

\section{CONCLUSION}

After controlling for non-traditional student characteristics, Black and Hispanic STEM majors were significantly underrepresented online, with Black and Hispanic males particularly underrepresented, followed by Hispanic females. This is problematic because it implies that students who are already underrepresented in STEM disciplines are less likely to develop online learning skills that are increasingly being viewed as essential by employers, who increasingly value technical skills, and the majority of which now conduct online training (e.g. Mossberger, Tolbert C. J., \& McNeal, 2007).

In contrast, female STEM majors are overrepresented in online courses, implying that online STEM courses may be a tool for increasing the representation of women in STEM courses, and that such courses may promote higher rates of STEM degree completion among women; future research exploring this relationship could be critical for understanding how to support female STEM majors.

While non-traditional student characteristics were important predictors of online enrollment for all majors, they were particularly important predictors for STEM students in this study. STEM majors with non-traditional student characteristics were significantly more likely 
to enroll in online courses, even when ethnicity, gender, academic preparation, and SES were controlled. STEM majors who had ever taken a remedial course or who had attended multiple institution types (other potential markers of non-traditional status) were also significantly more likely to enroll online. And students at less selective and public institutions (where there are higher numbers of non-traditional and disadvantaged students) were significantly more likely to enroll online. The greater the number of non-traditional characteristics that a student possessed, the more likely they were to enroll online. Specifically, STEM majors who were financially independent, who were 24 years of age or older, who had young children, who worked full-time while enrolled, who were married, or who were active duty military were all significantly more likely to enroll in online courses, even when other factors were controlled.

This suggests that STEM majors who have traditionally been less likely to pursue higher education (and who are less likely to persist once they enroll) may be more likely to enroll in courses if they are offered online. This fact leads to two particularly important implications: 1) Limiting access to online STEM courses may impede college access and degree progress for non-traditional students if these students do not substitute face-to-face sections of courses for online sections when a particular course is not offered online, and therefore institutions should be cautious about limiting access to online courses; and 2) Future observational studies that aim to explore online versus face-to-face outcomes must include a wider array of non-traditional student characteristics if they are to rigorously control for the self-selection of STEM majors into online courses. 


\section{REFERENCES}

Authors, 2009

Authors, 2011

Authors, 2012a

Authors, 2012b

Authors, In Press [a]

Authors, In Press [b]

Allen, J., Robins, S.B., Casillas, A. \& Oh, I-S. (2008). Third year college retention and transfer: Effects of academic performance, motivation and social connectedness. Research in Higher Education, 29(7), 647-664.

Allen, I.E. \& Seaman, J. (2007). Online Nation: Five years of growth in online learning. Sloan Foundation Publication. http://files.eric.ed.gov/fulltext/ED529699.pdf

Allen, I.E. \& Seaman, J. (2010). Class differences: Online education in the United States, 2010. Sloan Foundation Publication. http://sloanconsortium.org/publications/survey/pdf/class_differences.pdf.

Allen, I.E. \& Seaman, J. (2013). Changing course: Ten years of tracking online education in the United States. Babson Survey Research Group and Quahog Research Group, LLC. http://www.onlinelearningsurvey.com/reports/changingcourse.pdf.

Angiello, R. S. (2002). Enrollment and success of Hispanic students in online courses. http://www.eric.ed.gov/contentdelivery/servlet/ERICServlet?accno=ED469358.

Anderson, E. \& Kim, D. (2006). Increasing the success of minority students in science and technology. American Council on Education. http://opas.ous.edu/Committees/Resources/Publications/ACE-MinorityStudents.pdf.

Aragon, S., \& Johnson, E. (2008). Factors influencing completion ad noncompletion of comunity college online courses. The American Journal of Distance Education, 22, 146-158.

Attewell, P., Heil, S., \& Reisel, L. (2012). What Is Academic Momentum? And Does It Matter? Educational Evaluation and Policy Analysis, 34(1), 27-44. doi: 10.3102/0162373711421958

Babco, E. (2004). Skills for the innovation economy: What the 21st century workforce needs and how to provide it. Washington, DC: Commission on Professionals in Science and Technology. 
Bean, J. P. (1990). Why students leave: Insights from research. In D. Hossler \& J. P. Bean (Eds.), The strategic management of college enrollments (pp. 147-169). San Francisco, CA: Jossey-Bass.

Bean, J. P., \& Metzner, B. S. (1985). A conceptual model of nontraditional undergraduate student attrition. Review of Educational Research, 55 (4), pp. 485-540.

Borenstein, M., Hedges, L. V., Higgins, J. P. T., \& Rothstein, H. R. (2009). Converting among effect sizes. Introduction to meta-analysis (pp. 45-49) John Wiley \& Sons, Ltd. doi:10.1002/9780470743386.ch7

Braxton, J. M., Bray, N. J., \& Berger, J. B. (2000). Faculty teaching skills and their influence on the college student departure process. Journal of College Student Development, 41, 215227.

Burnham, K. P. \& Anderson, D.R. (2002). Model Selection and Multimodel Inference: A Practical Information-Theoretic Approach. Springer-Verlag, New York, NY.

Carr, S. (2000). As distance education comes of age, the challenge is keeping the students. The Chronicle of Higher Education, 46(3), A39-A41.

Community College Research Center (CCRC). (2013). Research Overview/April 2013: What we know about online course outcomes. Retrieved from http://ccrc.tc.columbia.edu/publications/what-we-know-online-course-outcomes.html

Conway, K.M., Wladis, C.W. and Hachey, A.C. (2011). Minority student access in the online environment. HETs (Hispanic Educational Technologies Services) Online Journal, 2(1), October

Conway, K.M., Wladis, C.M., \& Hachey, A.C. (2012). Black and Hispanic males in the online STEM environment. Paper presented at the Sixth Annual Black, Brown and College Bound Conference, February/March, 2012, Tampa, FL.

Chee, K. H. (2005). Gender differences in the academic ethic and academic achievement. College Student Journal, 39(3), 604-618.

Chen, P-S. D., Lambert, A. D. \& Guidry, K.R. (2010). Engaging online learners: The impact of Web-based learning technology on college student engagement. Computers \& Education, 54(4), 1222-1232. 
Chen, X. \& Weko, T. (2009). "Students who study science, technology, engineering and mathematics (STEM) in post-secondary education.” NCES 2009-161. Washington, D.C.: U.S. Department of Education, National Center for Education Statistics.

Choy, S.P. (2001). Students whose parents did not go to college: Postsecondary access, persistence and attainment. National Center for Education Statistics (NCES)- Findings from the Condition of Education 2001. nces.ed.gov/pubs2001/2001126.pdf.

Contento, J. M. (1999). Impacts of financial aid on persistence: A longitudinal analysis of beginning undergraduate students. Doctoral dissertation, Arizona State University. Dissertation Abstracts International, 60, 657.

DeBerard, M.S., Spielmans, G.I. \& Julka, D.C. (2004). Predictors of Academic achievement and retention among college freshmen: A longitudinal study. College Student Journal 38(1), 66-80.

Deming D., Goldin C., Katz L.F., \& Yuchtman N. (2015) Can online learning bend the cost curve of higher education? American Economic Review, American Economic Association, 105(5), pages 496-501, May.

DesJardins, S. L., Ahlburg, D. A., \& McCall, B. P. (1999). An event history model of student departure. Economics of Education Review, 18, 375-390.

Downes, S. (2005). E-Learning 2.0. eLearn Magazine. http://www.elearnmag.org/subpage.cfm?article=29-1\&section=articles.

Dupin-Bryant, P. (2004). Pre-entry variables related to retention in onine distance education. American Journal of Distance Education, 18(4), 1999.

Dutton, J., Dutton, M., \& Perry, J. (2002). How do online students differ from lecture students? Journal for Asynchronous Learning Networks, 6(1), 1-20.

Erisman, W. \& Looney, S. (2007). Opening the door to the American Dream: Increasing higher education access and success for immigrants. A report by the Institute for Higher Education Policy. http://www.dsa.csupomona.edu/ab540/files/OpeningTheDoor_8059.pdf.

Fairlie, R. (2007) Explaining Differences in Access to Home Computers and the Internet: A Comparison of Latino Groups to Other Ethnic and Racial Groups, Electronic Commerce Research, 7, 265-291. http://people.ucsc.edu/ rfairlie/papers/published/ecr\%202007\%20\%20latino\%20technology.pdf. 
File, T. (2013). Computer and Internet use in the United States. Current Population Survey Reports, 20-568. U.S. Census Bureau, Washington, DC.

Freeman, C. E. (2004). Trends in educational equity of girls and women: 2004. National Center for Education Statistics. Washington, DC: National Center for Educational Statistics.

Furr, S. R., \& Elling, T. W. (2002). African American students in a predominantly White university: Factors associated with retention. College Student Journal, 36, 188-199.

George, Y.S., Neale D.S., Van Horne, V. \& Malcom, S.M. (2001). In pursuit of a diverse Science, Technology, Engineering, and Mathematics workforce: Recommended research priorities to enhance participation by underrepresented minorities. Report from the American Association for the Advancement of Science, December, Washington, DC. http://ehrweb.aaas.org/mge/Reports/Report1/AGEP/?downloadURL=true\&loId=EB79A2 C2-3280-4404-AAF3-0D5D3F8A9D6D.

Guri-Rosenblit, S. (1999). Distance and campus universities: Tensions and interactions. Oxford, U.K.: IAU Press.

Halsne, A.M. \& Gatta, M.A. (2002). Online Versus Traditionally-delivered Instruction: A Descriptive Study of Learner Characteristics in a Community College Setting. Online Journal of Distance Learning Administration 5(1), Spring.

Huang, G., Taddese, N., \& Walter, E. (2000). Entry and persistence of women and minorities in college science and engineering education. U.S. Department of Education. National Center for Education Statistics. NCES 2000-601, Washington, DC: 2000.

Howell, S.L., Williams, P.B. \& Lindsay, N.K. (2011). Thirty-two trends affecting distance education: An informed foundation for strategic planning. Retrieved from http://umsl.edu/ wilmarthp/modla-links-2011/32_trends_affecting_DL.pdf.

Ishitani, T. T., \& DesJardins, S. L. (2002). A longitudinal investigation of dropout from college in the United States. Journal of College Student Retention, 4, 173-201.

Jaggars, S. S. (2011). Online learning: Does it help low-income and underprepared students? (CCRC Working Paper 26) Community College Research Center, Columbia University. Retrieved from http://ccrc.tc.columbia.edu/media/k2/attachments/online-learning-helpstudents.pdf 
Jaggars, S., \& Xu, D. (2010). Online learning in the Virginia community college system. Retrieved from Commuity College Research Center, Teachers College, Columbia University.

Jaggars, S. \& Xu, D. (2013). Adaptability to online learning: Differences across types of students and academic areas (CCRC Working Paper \#54). New York, New York: Columbia University, Teachers College, Community College Research Center.

Jones, E. (2010). Exploring common characteristics among community college studnets: Comparing onine and traditional student success. PhD Dissertation, Appalachian State University.

Jones, L., Castellanos, J., \& Cole, D. (2002). Examining the ethnic minority student experience at predominately White institutions: A case study. Journal of Hispanic Higher Education, $1(1), 19-39$.

Lacek, W. E. (1996). Gender differences among incoming African American freshmen on academic and social expectations. Journal of the Freshman Year Experience, 8(1), 25-37.

Kember, D. (1989). A longitudinal-process model of drop-out from distance education. Journal of Higher Education, 60 (3), 278-301.

Kember, D. (1995). Open learning courses for adults: A model of student progress. Englewood Cliffs, New Jersey, U.S.: Educational Technology Publications.

Kurlaender, M. \& Howell, J. (2012). Academic Preparation for College: Evidence on the Importance of Academic Rigor in High School. Background Paper of the College Board Advocacy \& Policy Center. Retrieved from https://advocacy.collegeboard.org/sites/default/files/affinity-network-academicpreparation-college.pdf

Lascher, Jr., E.L. (2008). Retaining Latino and Non-Latino College Students: Key Similarities and Differences. Working paper for the Serna Center and the Institute for Higher Education Leadership and Policy. http://www.csus.edu/sernacenter/assets/publications/retention.pdf.

Layne, M., Boston, W.E. \& Ice, P. (2013). A longitudinal study of online learners: Shoppers, swirlers, stoppers, and succeeders as a function of demographic characteristics. Online Journal of Distance Learning Administration, 16(2), Summer. 
Leppel, K. (2002). Similarities and differences in the college persistence of men and women. The Review of Higher Education, 25, 433-450.

Lopez, M.H., Gonzalez-Barrera, A. \& Patten, E. (2013) Closing the digital divide: Latinos and technology adoption. Pew Research Hispanic Center. http://www.pewhispanic.org/2013/03/07/closing-the-digital-divide-latinos-andtechnology-adoption/.

Long-Goding, J.L. (2006). Student Success in an Online Learning Environment. A Paper Presented in Partial Fulfillment of the Requirements of ED 7212, Administration and Leadership of Distance Education. Capella University, June 22, 2006. http://www.decadeconsulting.com/dc/documents/StudentSuccess.pdf.

Lufkin, M. (2008). The STEM Equity Pipeline. North Carolina Career Tech Prep Conference. North Carolina Department of Public Instruction, North Carolina Community Colleges. March 3-4, 2008. http://www.napequity.org/page.php?28.

Lufkin, M. (2008). The STEM Equity Pipeline. North Carolina Career Tech Prep Conference. North Carolina Department of Public Instruction, North Carolina Community Colleges. March 3-4, 2008. http://www.napequity.org/page.php?28.

Mood, C. (2010). Logistic regression: Why we cannot do what we think we can do and what we can do about it. European Sociological Review, 26(1), 67-82.

Moody, J. (2004). Distance education: Why are the attrition rates so high?. The Quarterly Review of Distance Education, 5(3), 205-210.

Mooney, G.M. \& Foley, D.J. (2011). Community colleges: Playing an important role in the education of science, engineering, and health graduates. Info Brief NSF 11-317, National Center for Science and Engineering Statistics, June 2011.

Moore, K., Bartkovich, J., Fetzner, M., \& Ison, S. (2004). Success in cyberspace: Student retention in online sources. Jurnalof Applied Research in the Community College, 10(2), 107-118.

Moore, M., \& Kearsley, G. (2005). Distance education: A systems view. Belmont, CA, U.S.: Wadsworth Publishing.

Morris, L.V. \& Finnegan, C.L. (2008-9). Best practices in predicting and encouraging student persistence and achievement online. Journal of College Student Retention: Research, Theory \& Practice, 10(1), 55-64. 
Morris, L., Wu, S., \& Finnegan, C. (2005). Predicting retention in online general education courses. American Journal of Distance Education, 19(1), 23.

Mossberger, K., Tolbert C. J., \& McNeal, R. S. (2007). Digital citizenship: The internet, society and participation. Cambridge, MA: The MIT Press.

Murtaugh, P. A., Burns, L. D., \& Schuster, J. (1999). Predicting the retention of university students. Research in Higher Education, 40(3), 355-371.

Muse, H. (2003). The web-based community college student: An examination of factors that lead to success and risk. The Internet and Higher Education, 6(3), 241-261.

National Science Board (2008). Science and Engineering Indicators 2008. Two volumes (volume 1, NSB 08-01; volume 2, NSB 08-01A). Arlington, VA: National Science Foundation.

National Center for Education Statistics (NCES). (2009). Beginning postsecondary students longitudinal study. Washington, D.C.: U.S. Department of Education. Retrieved from http://nces.ed.gov/surveys/bps/

National Center for Education Statistics (NCES). (2012). National postsecondary student aid study (NPSAS). Retrieved from http://nces.ed.gov/surveys/npsas/

National Center for Education Statistics (NCES). (1995). Profile of Undergraduates in U.S. Postsecondary Education Institutions: 1992-93. With an Essay on Undergraduates at Risk. http://0-nces.ed.gov.opac.acc.msmc.edu/pubs/96237.pdf.

National Center for Education Statistics (NCES). (1996). Post-secondary descriptive analyst report- Non-traditional Undergraduates: Trends in enrollment from 1986 to 1992 and Persistence and attainment among beginning post-secondary students. http://nces.ed.gov/pubs/97578.pdf.

National Center for Education Statistics (NCES). (2002). Findings from the condition of education: Non-traditional undergraduates. http://nces.ed.gov/pubs2002/2002012.pdf. National Center for Education Statistics (NCES). (2005). The condition of education. National Center for Education Statistics, Washington, DC.

National Center for Education Statistics (NCES). (2008). PowerStats: NPSAS: 2008 Undergraduate, all variables by variable name. http://nces.ed.gov/datalab/powerstats/pdf/npsas2008ug_varname.pdf. 
National Science Board (2008). Science and Engineering Indicators 2008. Two volumes (volume 1, NSB 08-01; volume 2, NSB 08-01A). Arlington, VA: National Science Foundation.

http://www.nsf.gov/od/oia/activities/ceose/reports/ceose2004report.pdf.

National Science Foundation (2005). Science and Engineering Indicators: 2004. http://www.nsf.gov/statistics/seind04/c1/c1h.htm.

National Science Foundation, National Center for Science and Engineering Statistics (NSF/NCSES). (2011). Women, Minorities, and Persons with Disabilities in Science and Engineering: 2011. Special Report NSF 11-309. Arlington, VA. http://www.nsf.gov/ statistics/wmpd/.

The New American Consumer (2012). The New American Consumer: State of the Hispanic Consumer Marketplace. Experian Marketing Services. http://ahaa.org/downloads/Research/marketig-services-hispanic-demographic-report-112012.pdf.

Norris, S. (2002). Tracking the progress of change in U.S. undergraduate education in Science, Mathematics, Engineering and Technology. Science Education, 86(1), 79-105.

Obama (2012). Remarks by the President in state of the union address on January 25, 2012. http://www.whitehouse.gov/the-press-office/2012/01/24/remarks-president-state-unionaddress.

O’Brien, R. M. (2007). A Caution Regarding Rules of Thumb for Variance Inflation Factors. Quality \& Quantity, 41 (5): 673. DOI:10.1007/s11135-006-9018-6

Parsad, B., Lewis, L. \& Tice, P. (2008). Distance education at degree-granting postsecondary institutions: 2006-07. NCES 2009-044. National Center for Education Statistics, U.S. Dept. of Education.

Patterson, B., \& McFadden, C. (2009). Attrition in onine and campus degree programs. Journal of Distance Learning Administration, 12(2), Summer.

Paulsen, M. B., \& St. John, E. P. (2002) Social class and college costs: Examining the financial nexus between college choice and persistence. The Journal of Higher Education, 73 (2), 198-236.

Pearson Foundation. (2011). Community College Student Survey: Summary of Results. Pearson Foundation. 
http://www/pearsonfoundation.org/downloads/Community_College_Survey_Summary_2 01102.pdf.

Pontes, M., Hasit, C., Pontes, N., Lewis, P., \& Siefring, K. (2010). Variables related to undergraduate students preference for distance education classes. Online Journal of Distance Learning Administration, 13(2), 8.

Preacher, K. J., \& Hayes, A. F. (2008). Asymptotic and resampling strategies for assessing and comparing indirect effects in multiple mediator models. Behavior Research Methods, 40, 879-891.

Qureshi, E., Morton, L., \& Antosz, E. (2002, Winter). An interesting profile - University students who take distance education courses show weaker motivation than on campus students. Online Journal of Distance Learning Administration, V(IV)

Rainie, L. (2010). Internet, broadband, and cell phone statistics. Washington, DC: Pew Internet. http://pewinternet.org/Reports/2010/Internet-broadband-and-cell-phone-statistics.aspx.

Rovai, A.P. (2002). Building a sense of community at a distance. The International Review of Research in Open and Distance Learning, 3(1). http://www.irrodl.org/index.php/irrodl/article/viewArticle/79/152

Rovai, A. P. (2003). In search of higher persistence rates in distance education online programs. Internet and Higher Education, 6(1), 1-16. doi:10.1016/S1096-7516(02)00158-6

Sankaran, S. R., \& Sankaran, D. (March 2000). Effect of student attitude to course format on learning performance: an empirical study in web vs. lecture instruction. Journal of Instructional Psychology, 27(1), 66-73.

Schneider, B., Martinez, S. \& Ownes, A. (2006). Barriers to Educational Opportunities for Hispanics in the United States. In M. Tienda \& F. Mitchell, (Eds.). Hispanics and the Future of America. National Research Council (US) Panel on Hispanics in the United States; Washington (DC): National Academies Press (US).

Shea, P. \& Bidjerano, T. (2014). Does online learning impede degree completion? A national study of community college students. Computers \& Education, 75, 103-111.

Shapiro, D., Dundar, A., Chen, J., Ziskin, M., Park, E., Torres, V., \& Chiang, Y. (2013, February). Completing College: A State-Level View of Student Attainment Rates (Signature Report No. 4a). Herndon, VA: National Student Clearinghouse Research Center. http://nscresearchcenter.org/signaturereport4-statesupplement/ 
Tinto, V. (1975). Dropout from higher education: A theoretical synthesis of recent research. Review of Educational Research, 45(89), 125. doi:10.3102/00346543045001089

Tinto, V. (1986). Theories of student departure revisited. In J. C. Smart (Ed.), Higher education handbook of theory and research. Volume Two. (pp. 359-384). New York; NY; U.S.: Agathon Press.

Tinto, V. (1993). Leaving college: Rethinking the causes and cures of student attrition. Second edition. Chicago, IL: University Of Chicago Press.

Titus, M. A. (2006). Understanding the influence of the financial context of institutions on student persistence at four-year colleges and universities. The Journal of Higher Education, 77(2), 353-375.

U.S. Department of Commerce (2011). Women in STEM: A Gender Gap to Innovation. Economics and Statistics Administration. http://www.esa.doc.gov/sites/default/files/reports/documents/womeninstemagaptoinnovat ion8311.pdf.

U.S. Department of Education. (2013). IPEDS Spring 2013, Fall Enrollment component (provisional data). National Center for Education Statistics (NCES). Washington, D.C.: U.S. Department of Education. Retrieved from http://nces.ed.gov/pubs2014/2014023.pdf

U.S. Department of Education. (1999). National postsecondary student aid study (NPSAS). National Center for Education Statistics (NCES 1999-030).

U.S. Department of Education (2009). Students who study science, technology, engineering, and mathematics (STEM) in postsecondary education National Center for Education Statistics. Report NCES 2009-161, July 2009. http://nces.ed.gov/pubs2009/2009161.pdf.

U.S. Department of Education (2011). Postsecondary awards in Science, Technology, Engineering, and Mathematics, by State: 2001 and 2009. National Center for Education Statistics. NCES 2011-226. http://nces.ed.gov/pubs2011/2011226.pdf.

Voorhees, R. A., \& Zhou, D. (2000). Intentions and goals at the community college: Associating student perceptions and demographics. Community College Journal of Research and Practice, 24(3), 219-232.

Walpole, M. (2003). Socioeconomic status and college: How SES affects college experiences and outcomes. The Review of Higher Education, 27(1), 45-73. 
Xu, D., \& Jaggars, S. (2011). The effectiveness of distance education across Virginia's community colleges: Evidence from introductory college-level math and English courses. Educational Evaluation and Policy Analysis, 33(3), 360-377. 
Table 1. Distribution of majors among total NPSAS sample, among all students who did not enroll in an online course in 2007-2008, and among all students who did enroll in an online course in 2007-2008

\begin{tabular}{|c|c|}
\hline & $\begin{array}{ll}\text { Pct. } & {[95 \% \mathrm{Cl}]}\end{array}$ \\
\hline & Agriculture and related sciences \\
\hline total & $2.8 \% \quad[2.5-3.2 \%]$ \\
\hline not online & $2.9 \% \quad[2.5-3.4 \%]$ \\
\hline \multirow[t]{2}{*}{ online } & $2.3 \%[1.7-3.1 \%]$ \\
\hline & Natural resources and conservation \\
\hline total & $1.3 \% \quad[1.1-1.6 \%]$ \\
\hline not online & $1.4 \%[1.1-1.7 \%]$ \\
\hline \multirow[t]{2}{*}{ online } & $1.0 \%[0.0-1.6 \%]$ \\
\hline & Computer and information sciences \\
\hline total & $18.1 \%[17.2-19.0 \%]$ \\
\hline not online & $16.1 \%[15.2-17.1 \%]$ \\
\hline \multirow[t]{2}{*}{ online } & $27.2 \%[24.7-29.8 \%]$ \\
\hline & Engineering and engineering technologies \\
\hline total & $25.7 \%[24.5-26.9 \%]$ \\
\hline not online & $26.2 \%[25.1-27.4 \%]$ \\
\hline \multirow[t]{2}{*}{ online } & $23.0 \%[20.7-25.6 \%]$ \\
\hline & Biological and biomedical sciences \\
\hline total & $14.4 \%[13.8-15.1 \%]$ \\
\hline not online & $15.2 \%[14.5-16.0 \%]$ \\
\hline \multirow[t]{2}{*}{ online } & $10.7 \%[9.4-12.2 \%]$ \\
\hline & Mathematics and statistics \\
\hline total & $2.6 \% \quad[2.3-2.8 \%]$ \\
\hline not online & $2.6 \% \quad[2.3-3.0 \%]$ \\
\hline \multirow[t]{2}{*}{ online } & $2.2 \%[1.5-3.1 \%]$ \\
\hline & Physical sciences \\
\hline total & $4.3 \%[3.9-4.7 \%]$ \\
\hline not online & $4.6 \%[4.2-5.0 \%]$ \\
\hline \multirow[t]{2}{*}{ online } & $3.0 \% \quad[2.3-3.9 \%]$ \\
\hline & Science technologies/technicians \\
\hline total & $1.2 \%[0.0-1.5 \%]$ \\
\hline not online & $1.1 \%[0.0-1.5 \%]$ \\
\hline \multirow[t]{2}{*}{ online } & $1.7 \% \quad[1.2-2.5 \%]$ \\
\hline & Social sciences \\
\hline total & $29.7 \% \quad[28.6-30.7 \%]$ \\
\hline not online & $29.9 \%$ [28.7-31.0\%] \\
\hline online & $28.9 \%[26.7-31.1 \%]$ \\
\hline
\end{tabular}

Notes: Variance estimation was computed using Balanced Repeated Replication with 200 replicates. The weight variable used in this table is WTA000.

Source: U.S. Department of Education, National Center for Education Statistics, 2007-08 National Postsecondary Student Aid Study (NPSAS:08). 

(Odds Ratios Reported ${ }^{a}$ )

\begin{tabular}{|c|c|c|c|c|c|}
\hline \multirow[b]{2}{*}{ Intercept } & STEM & \multicolumn{3}{|c|}{ non-STEM } & \multirow[t]{3}{*}{ Interaction $^{d}$} \\
\hline & 0.1118 & $* * *$ & 0.1596 & $* * *$ & \\
\hline & $(0.0068)$ & & $(0.0054)$ & & \\
\hline \multicolumn{6}{|l|}{ Race/ethnicity } \\
\hline \multirow[t]{2}{*}{ Black or African American } & 0.8444 & $*$ & 0.7138 & $* * *$ & \\
\hline & $(0.0692)$ & & $(0.0345)$ & & \\
\hline \multirow[t]{2}{*}{ Hispanic or Latino } & 0.6845 & $* * *$ & 0.6203 & $* * *$ & \\
\hline & $(0.0584)$ & & $(0.0318)$ & & \\
\hline \multirow{2}{*}{ Asian } & 0.8077 & * & 0.8182 & * & . \\
\hline & $(0.0807)$ & & $(0.0659)$ & & \\
\hline \multirow[t]{2}{*}{ Other } & 0.7955 & & 0.826 & $*$ & \\
\hline & $(0.1133)$ & & $(0.0626)$ & & \\
\hline \multicolumn{6}{|l|}{ Gender } \\
\hline \multirow[t]{2}{*}{ Female } & 1.2484 & $* * *$ & 1.1219 & $* * *$ & \\
\hline & $(0.0549)$ & & $(0.032)$ & & \\
\hline \multicolumn{6}{|c|}{ Index of risk and nontraditional students ${ }^{b}$} \\
\hline \multirow[t]{2}{*}{ One } & 1.7347 & $* * *$ & 1.3088 & $* * *$ & $*$ \\
\hline & $(0.1274)$ & & $(0.0607)$ & & \\
\hline \multirow[t]{2}{*}{ Two } & 2.2967 & $* * *$ & 1.7599 & $* * *$ & $*$ \\
\hline & $(0.1963)$ & & $(0.0938)$ & & \\
\hline \multirow[t]{2}{*}{ Three } & 3.3188 & $* * *$ & 2.442 & $* * *$ & $* * *$ \\
\hline & $(0.2901)$ & & $(0.1283)$ & & \\
\hline \multirow[t]{2}{*}{ Four } & 3.8374 & $* * *$ & 2.7752 & $* * *$ & $* *$ \\
\hline & $(0.3572)$ & & $(0.1306)$ & & \\
\hline \multirow[t]{2}{*}{ Five or More } & 4.1393 & $* * *$ & 2.8201 & $* * *$ & $* * *$ \\
\hline & $(0.3898)$ & & $(0.1523)$ & & \\
\hline coarsened $N^{c}$ & 27,800 & & 76,000 & & \\
\hline
\end{tabular}

Notes: Standard errors are in parentheses. Variance estimation was computed using Balanced Repeated Replication with 200 replicates. The weight variable used in this table is WTA000. ${ }^{a}$ Odds ratios are one kind of effect size (see e.g. (Borenstein, Hedges, Higgins, \& Rothstein, 2009), with values farther away from 1 representing a larger effect, and the values $n$ and $1 / n$ representing an effect of the same size, but in opposite directions (the first is greater than one, the second is less than one). ${ }^{b}$ This index measures how many of the following seven characteristics apply to a given student: Delayed enrollment; No high school diploma; Part-time enrollment; Financially independent; Have dependents; Single parent status; Working full-time while enrolled ${ }^{c}$ Per NCES Standards, the true sample size has been modified to minimize disclosure risk of individual survey responses.

${ }^{d}$ This column indicates whether the interaction between the factor and major type (STEM vs. nonSTEM) was significant in the overall model containing both STEM and non-STEM majors. A test of overall model fit, by testing the model with the interaction of major (STEM vs. non-STEM) with all of the other independent variables was significant: using the weighted deviance difference method for comparing the $F$ statistic of both the model with the interactions and the one without, the model with the interactions was a significantly better fit with $p=0.0002$.

- $p<0.10, * p<0.05, * * p<0.01, * * * p<0.001$

Source: U.S. Department of Education, National Center for Education Statistics, 2007-08 National Postsecondary Student Aid Study (NPSAS:08). 
Table 3 Separate Logistic Regression Models for each group of potential student-level factors affecting online course enrollment, for STEM majors (Odds Ratios Reported)

\begin{tabular}{|c|c|c|c|c|c|c|c|}
\hline & ethnicity & gender & non-trad. & acad. prep. & SES & ESL/citz. & full \\
\hline Intercept & $\begin{array}{l}0.2238^{* * *} \\
(0.0171)\end{array}$ & $\begin{array}{l}0.2003^{* * *} \\
(0.0151)\end{array}$ & $\begin{array}{l}0.1150 \text { *** } \\
(0.0112)\end{array}$ & $\begin{array}{l}0.1666^{* * *} \\
(0.0531)\end{array}$ & $\begin{array}{l}0.2848 \text { *** } \\
(0.0379)\end{array}$ & $\begin{array}{l}0.2194^{* * *} \\
(0.0146)\end{array}$ & $\begin{array}{l}0.0969 \text { *** } \\
(0.0158)\end{array}$ \\
\hline \multicolumn{8}{|c|}{ Race/ethnicity (Ref gp: White) } \\
\hline Black or African American & $\begin{array}{r}1.0819 \\
(0.1856)\end{array}$ & & & & & & $\begin{array}{c}0.8367 * \\
(0.0739)\end{array}$ \\
\hline Hispanic or Latino & $\begin{array}{l}0.7892 * * \\
(0.1242)\end{array}$ & & & & & & $\begin{array}{l}0.6757 \text { *** } \\
(0.0660)\end{array}$ \\
\hline Asian & $\begin{array}{c}0.7334^{* *} \\
(0.1421)\end{array}$ & & & & & & $\begin{array}{r}0.8313 \\
(0.1028)\end{array}$ \\
\hline Other & $\begin{array}{r}0.9175 \\
(0.2394)\end{array}$ & & & & & & $\begin{array}{r}0.7597 \text {. } \\
(0.1127)\end{array}$ \\
\hline \multicolumn{8}{|l|}{ Gender (Ref gp: Male) } \\
\hline Female & & $\begin{array}{l}1.1678^{* * *} \\
(0.0995)\end{array}$ & & & & & $\begin{array}{l}1.21711^{* * *} \\
(0.0561)\end{array}$ \\
\hline \multicolumn{8}{|c|}{ Index of risk and nontraditional students ${ }^{a}$ (Ref gp: None) } \\
\hline One & & & $\begin{array}{l}1.6739 \text { *** } \\
(0.2431)\end{array}$ & & & & $\begin{array}{l}1.6837^{* * *} \\
(0.1245)\end{array}$ \\
\hline Two & & & $\begin{array}{l}2.2080 \text { *** } \\
(0.3656)\end{array}$ & & & & $\begin{array}{l}2.1713 \text { *** } \\
(0.1902)\end{array}$ \\
\hline Three & & & $\begin{array}{l}3.1650 \text { *** } \\
(0.5431)\end{array}$ & & & & $\begin{array}{l}3.0634 \text { *** } \\
(0.3045)\end{array}$ \\
\hline Four & & & $\begin{array}{l}3.6879 * * * \\
(0.6667)\end{array}$ & & & & $\begin{array}{l}3.2212 \text { *** } \\
(0.3751)\end{array}$ \\
\hline Five or More & & & $\begin{array}{l}3.9764 \text { *** } \\
(0.7446)\end{array}$ & & & & $\begin{array}{l}3.3448 * * * \\
(0.4224)\end{array}$ \\
\hline Grade point average & & & & $\begin{array}{l}1.0008 \text {. } \\
(0.0008)\end{array}$ & & & $\begin{array}{r}1.0006 \\
(0.0004)\end{array}$ \\
\hline \multicolumn{8}{|l|}{ Remedial courses: Ever taken } \\
\hline Yes & & & & $\begin{array}{l}1.4169 * * * \\
(0.2165)\end{array}$ & & & $\begin{array}{l}1.3786 \text { *** } \\
(0.1079)\end{array}$ \\
\hline
\end{tabular}




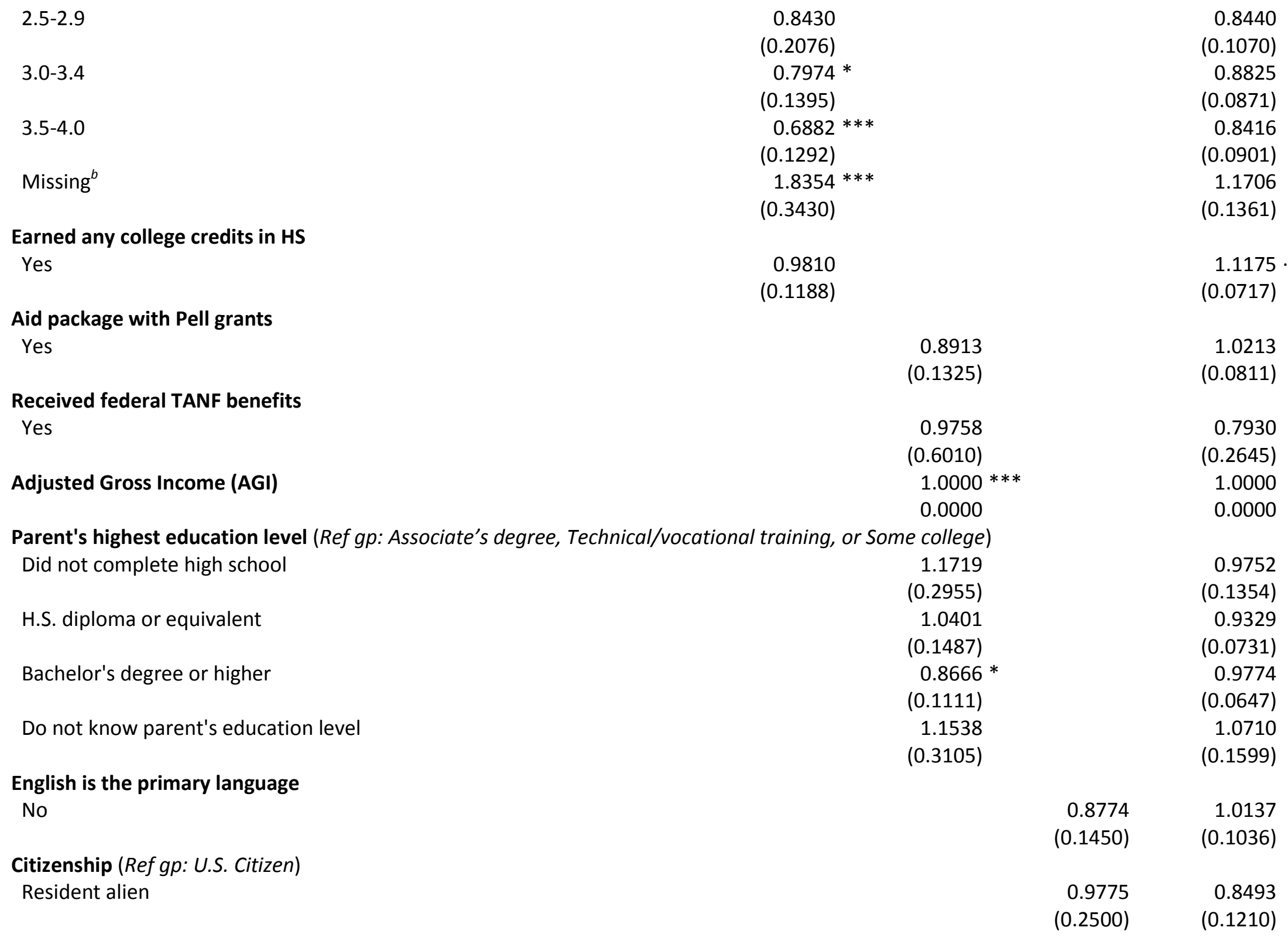




\begin{tabular}{|c|c|c|c|c|c|c|c|}
\hline \multicolumn{6}{|c|}{ Foreign or international student } & \multirow{2}{*}{$\begin{array}{r}0.7319 \\
(0.2950) \\
27,800\end{array}$} & \multirow{2}{*}{$\begin{array}{r}0.8475 \\
(0.1955) \\
26,700\end{array}$} \\
\hline coarsened $N^{c}$ & 27,800 & 27,800 & 27,800 & 27,800 & 26,700 & & \\
\hline pseudo $R^{2}$ (Nagelkerke) & 0.0030 & 0.0015 & 0.0653 & 0.0427 & 0.0111 & 0.0012 & 0.0615 \\
\hline AIC & $3,799,242$ & $3,803,167$ & $3,641,512$ & $3,699,630$ & $3,653,089$ & $3,803,869$ & $3,477,491$ \\
\hline$p$-value, Wald F-statistic & $0.0023 * *$ & $0.0004 * * *$ & $0.0000 * * *$ & $0.0000 * * *$ & $0.0000 * * *$ & 0.0714 . & $0.0000 * * *$ \\
\hline
\end{tabular}

$\cdot p<0.10,{ }^{*} p<0.05,{ }^{* *} p<0.01, * * * p<0.001$

${ }^{a}$ This index measures how many of the following seven characteristics apply to a given student: Delayed enrollment; No high school diploma; Part-time enrollment; Financially independent; Have dependents; Single parent status; Working full-time while enrolled

${ }^{b}$ H.S. G.P.A. is missing for those students who took neither the ACT nor the SAT and/or for students 30 years or older.

${ }^{c}$ Per NCES Standards, the true sample size has been modified to minimize disclosure risk of individual survey responses.

Notes: Standard errors are in parentheses. Variance estimation was computed using Balanced Repeated Replication with 200 replicates. The weight variable used in this table is WTA000.

Source: U.S. Department of Education, National Center for Education Statistics, 2007-08 National Postsecondary Student Aid Study (NPSAS:08). 
Table 4 Separate Logistic Regression Models for each group of potential institutional-level factors affecting online course enrollment, for STEM majors (Odds Ratios Reported)

\begin{tabular}{|c|c|c|c|c|c|c|c|}
\hline & level & enr size & locale & private & selectivity & $\begin{array}{c}\text { minority } \\
\text { enrl }\end{array}$ & full model \\
\hline \multirow[t]{2}{*}{ Intercept } & $0.16 * * *$ & $0.19 * * *$ & $0.22 * * *$ & $0.22 * * *$ & $0.12 * * *$ & $0.22 * * *$ & $0.08 * * *$ \\
\hline & $(0.01)$ & $(0.01)$ & $(0.01)$ & $(0.01)$ & $(0.01)$ & $(0.02)$ & $(0.01)$ \\
\hline \multicolumn{8}{|c|}{ Level (Ref gp: Research \& Doctoral) } \\
\hline \multirow[t]{2}{*}{ Associate's } & $1.84 * * *$ & & & & & & 1.01 \\
\hline & $(0.13)$ & & & & & & $(0.24)$ \\
\hline \multirow[t]{2}{*}{ Master's } & $1.29 * *$ & & & & & & $1.35 * *$ \\
\hline & $(0.11)$ & & & & & & $(0.13)$ \\
\hline \multirow[t]{2}{*}{ Baccalaureate } & 0.91 & & & & & & 0.99 \\
\hline & $(0.13)$ & & & & & & $(0.16)$ \\
\hline \multirow[t]{2}{*}{ Special focus \& other } & $1.92 * *$ & & & & & & 1.57 \\
\hline & $(0.46)$ & & & & & & $(0.47)$ \\
\hline \multirow[t]{2}{*}{ Not degree granting } & $0.48 * * *$ & & & & & & $0.37 * *$ \\
\hline & $(0.10)$ & & & & & & $(0.12)$ \\
\hline \multirow[t]{2}{*}{ Enrollment size $^{a}$} & & $1.00 * * *$ & & & & & $1.00 * * *$ \\
\hline & & $(0.00)$ & & & & & $(0.00)$ \\
\hline \multicolumn{8}{|c|}{ Locale (Ref gp: large city/suburb) } \\
\hline \multirow{2}{*}{ midsize city/suburb } & & & 0.90 & & & & 0.98 \\
\hline & & & $(0.09)$ & & & & $(0.10)$ \\
\hline \multirow[t]{2}{*}{ small city/suburb } & & & 0.92 & & & & 0.99 \\
\hline & & & $(0.07)$ & & & & (0.09) \\
\hline \multirow[t]{2}{*}{ town/rural } & & & 1.03 & & & & 1.05 \\
\hline & & & $(0.09)$ & & & & $(0.11)$ \\
\hline \multicolumn{8}{|c|}{ Private/Public (Ref gp: public) } \\
\hline \multirow[t]{2}{*}{ Private not-for-profit } & & & & $0.53 * * *$ & & & 0.78 \\
\hline & & & & $(0.05)$ & & & $(0.08)$ \\
\hline \multirow[t]{2}{*}{ Private for-profit } & & & & 1.30 & & & 0.79 \\
\hline & & & & $(0.21)$ & & & $(0.15)$ \\
\hline \multirow{2}{*}{\multicolumn{2}{|c|}{ Attended more than one institution }} & & & $1.41 * * *$ & & & $1.40 * * *$ \\
\hline & & & & $(0.11)$ & & & $(0.11)$ \\
\hline
\end{tabular}

Selectivity (Ref gp: very selective) 
Moderately selective

Minimally selective

Open admission

Not public or private nfp 4-year
$1.57^{* * *}$

(0.13)

$1.82 * * *$

(0.21)

$2.64 * * *$

(0.52)

$2.70 * * *$

(0.21)
$1.44 * * *$

(0.13)

$1.72 * * *$

(0.23)

$2.59 * * *$

(0.54)

$2.87^{* * *}$

(0.70)

1.00 .

$(0.002)$

27,700

0.0512

$\begin{array}{lrrrrrrr}\text { coarsened } N^{c} & 27,800 & 27,700 & 27,800 & 27,800 & 27,800 & 27,600 & 27,700 \\ \text { pseudo } R^{2} \text { (Nagelkerke) } & 0.0199 & 0.0076 & 0.0007 & 0.0158 & 0.0314 & 0.0512 \\ \text { AIC } & 3,681,526 & 3,697,947 & 3,725,170 & 3,691,798 & 3,653,046 & 3,708,534 & 3,582,984\end{array}$

AIC $3,681,526$

$23.77 * * * \quad 1.0031$

$28.77 * *$

42.66

0.0243

$17.04 * * *$

- $p<0.10, * p<0.05, * * p<0.01, * * * p<0.001$

${ }^{a}$ While the odds ratio for enrollment size rounds to one (because the effect of an increase in enrollment size by one student is quite small), the relationship is positive.

${ }^{b}$ While the coefficient for percentage minority enrollment rounds to one, the relationship is negative in the base model that includes only percent minority enrollment, and positive in the full model that includes all institutional characteristics.

${ }^{c}$ Per NCES Standards, the true sample size has been modified to minimize disclosure risk of individual survey responses.

Notes: Standard errors are in parentheses. Variance estimation was computed using Balanced Repeated Replication with 200 replicates. The weight variable used in this table is WTA000.

Source: U.S. Department of Education, National Center for Education Statistics, 2007-08 National Postsecondary Student Aid Study (NPSAS:08). 
Table 5 Logistic Regression Model for full model of all potential student- and institutional-level factors affecting online course enrollment, for STEM majors (Odds Ratios Reported)

\begin{tabular}{|c|c|}
\hline \multicolumn{2}{|c|}{ M5 no int risk index } \\
\hline Intercept & $0.05 * * *$ \\
\hline Race/ethnicity (Ref gp: white) & $(0.01)$ \\
\hline Black or African American & $\begin{array}{r}0.88 \\
(0.09)\end{array}$ \\
\hline Hispanic or Latino & $\begin{array}{l}0.66 \text { *** } \\
(0.08)\end{array}$ \\
\hline Asian & $\begin{array}{r}0.85 \\
(0.11)\end{array}$ \\
\hline Other & $\begin{array}{c}0.73 \\
(0.13)\end{array}$ \\
\hline \multicolumn{2}{|l|}{ Gender (Ref gp: male) } \\
\hline Female & $\begin{array}{l}1.24 \text { *** } \\
(0.07)\end{array}$ \\
\hline \multicolumn{2}{|c|}{ Index of risk and nontraditional students ${ }^{a}$ (Ref gp: none) } \\
\hline One & $\begin{array}{l}1.55^{* * *} \\
(0.13)\end{array}$ \\
\hline Two & $\begin{array}{l}1.93 \text { *** } \\
(0.19)\end{array}$ \\
\hline Three & $\begin{array}{l}2.644^{* * *} \\
(0.28)\end{array}$ \\
\hline Four & $\begin{array}{l}2.96 \text { *** } \\
(0.42)\end{array}$ \\
\hline Five or More & $\begin{array}{l}2.97^{* * *} \\
(0.47)\end{array}$ \\
\hline $\mathrm{GPA}^{b}$ & $\begin{array}{r}1.00 * \\
(0.0005)\end{array}$ \\
\hline \multicolumn{2}{|l|}{ Remedial courses: Ever taken } \\
\hline Yes & $\begin{array}{l}1.37^{* * *} \\
(0.09)\end{array}$ \\
\hline \multicolumn{2}{|c|}{ Grade point average in high school (Ref gp: under 2.5) } \\
\hline 2.5-2.9 & $\begin{array}{r}0.80 \\
(0.11)\end{array}$ \\
\hline $3.0-3.4$ & $\begin{array}{r}0.88 \\
(0.11)\end{array}$ \\
\hline $3.5-4.0$ & $\begin{array}{r}0.87 \\
(0.10)\end{array}$ \\
\hline Missing $^{c}$ & $\begin{array}{r}1.10 \\
(0.15)\end{array}$ \\
\hline \multicolumn{2}{|c|}{ Earned any college credits in high school } \\
\hline yes & $\begin{array}{r}1.12 \\
(0.08)\end{array}$ \\
\hline \multicolumn{2}{|l|}{ Aid package with Pell grants } \\
\hline yes & $\begin{array}{r}1.05 \\
(0.08)\end{array}$ \\
\hline
\end{tabular}


$\begin{array}{lr}\begin{array}{lr}\text { Received TANF Benefits } \\ \text { yes }\end{array} & 0.67 \\ & (0.26) \\ \text { Adjusted Gross Income (AGI) }^{d} & 1.00 \\ & (0.00)\end{array}$

Parent's highest education level (Ref gp: Associate's degree, some college, or vocational degree)

Did not complete high school 0.96

0.92

$(0.08)$

Bachelor's degree or higher $\quad 0.99$

(0.07)

Do not know parent's education level 0.99

ESL

yes

Citizenship (Ref gp: citizen)

Resident alien

Foreign or international student

(0.22)

Enrollment size $e^{e}$

$1.00 * *$

$(0.00)$

Locale (Ref gp: large city/suburb)

midsize city/suburb

0.996

small city/suburb

(0.09)

town/rural

1.08

(0.11)

Level (Ref gp: Doctoral \& Research)

Associate's

Master's

1.16

(0.11)

Baccalaureate

0.88

(0.15)

Special focus \& other

1.37

(0.38)

Not degree granting

$0.36 * *$

$(0.12)$

Private vs Public (Ref gp: public)

Private not-for-profit

$0.76 * *$

(0.08)

Private for-profit 
Attended more than one institution

Selectivity (Ref gp: very selective)

Moderately selective

Minimally selective

Open admission

Not public or private nfp 4-year

Percent enrolled: White, non-Hispanic $f$

\begin{tabular}{lr}
\hline coarsened $N^{g}$ & 26,600 \\
pseudo $R^{2}$ (Nagelkerke) & 0.1036 \\
AIC & $3,330,511$ \\
$p$-value, Wald F-statistic & $14.27 * *$.
\end{tabular}

$\cdot p<0.10,{ }^{*} p<0.05,{ }^{* *} p<0.01,{ }^{* * *} p<0.001$

${ }^{a}$ This index measures how many of the following seven characteristics apply to a given student: Delayed enrollment; No high school diploma; Part-time enrollment; Financially independent; Have dependents;

Single parent status; Working full-time while enrolled

${ }^{b}$ While the odds ratio for GPA rounds to one (because the effect of an increase in GPA by one hundredth of a grade point is quite small), the relationship is positive.

${ }^{c}$ H.S. G.P.A. is missing for those students who took neither the ACT nor the SAT and/or for students 30 years or older.

${ }^{d}$ While the odds ratio for AGI rounds to one (because the effect of an increase in income by one dollar is quite small), the relationship is positive.

${ }^{e}$ While the odds ratio for enrollment size rounds to one (because the effect of an increase in enrollment size by one student is quite small), the relationship is positive.

${ }^{f}$ While the coefficient for percentage minority enrollment rounds to one, the relationship is positive.

${ }^{g}$ Per NCES Standards, the true sample size has been modified to minimize disclosure risk of individual survey responses.

Notes: Standard errors are in parentheses. Variance estimation was computed using Balanced Repeated Replication with 200 replicates. The weight variable used in this table is WTA000.

Source: U.S. Department of Education, National Center for Education Statistics, 2007-08 National Postsecondary Student Aid Study (NPSAS:08). 
Table 6 Logistic Regression Model from Table 5 (Ethnicity and Gender Combined) for Online Course Enrollment for STEM majors (Odds Ratios Reported Reported for ethnicity/gender factors only ${ }^{a}$ )

\begin{tabular}{|c|c|}
\hline & OR (SE) sig \\
\hline \multicolumn{2}{|c|}{ Race/ethnicity (with multiple) and gender } \\
\hline \multirow[t]{2}{*}{ Asian male } & 0.78 \\
\hline & $(0.13)$ \\
\hline \multirow[t]{2}{*}{ White Female } & $1.18 *$ \\
\hline & $(0.08)$ \\
\hline \multirow[t]{2}{*}{ Asian Female } & 1.12 \\
\hline & $(0.20)$ \\
\hline \multirow[t]{2}{*}{ Black male } & 0.80 . \\
\hline & $(0.11)$ \\
\hline \multirow[t]{2}{*}{ Hispanic male } & $0.62 * *$ \\
\hline & $(0.10)$ \\
\hline \multirow[t]{2}{*}{ Black female } & 1.15 \\
\hline & $(0.16)$ \\
\hline \multirow[t]{2}{*}{ Hispanic female } & 0.83 \\
\hline & $(0.12)$ \\
\hline \multirow[t]{2}{*}{ Other male } & 0.82 \\
\hline & $(0.21)$ \\
\hline \multirow[t]{2}{*}{ Other female } & 0.75 \\
\hline & $(0.19)$ \\
\hline coarsened $N^{b}$ & 26,600 \\
\hline pseudo $R^{2}$ (Nagelkerke) & 0.1041 \\
\hline AIC & $3,329,183$ \\
\hline$p$-value, Wald $F$-statistic & $13.02 * * *$ \\
\hline
\end{tabular}
$\cdot p<0.10, * p<0.05, * * p<0.01, * * * p<0.001$

${ }^{a}$ Model coefficients for all other factors were substantially similar to those in the full model in Table 3, and for the sake of brevity have been excluded here.

${ }^{b}$ Per NCES Standards, the true sample size has been modified to minimize disclosure risk of individual survey responses.

Notes: Standard errors are in parentheses. Variance estimation was computed using Balanced Repeated Replication with 200 replicates. The weight variable used in this table is WTA000.

Source: U.S. Department of Education, National Center for Education Statistics, 2007-08 National Postsecondary Student Aid Study (NPSAS:08). 
Table 7 Presence of at least one non-traditional risk factor as a mediator of ethnicity and gender for online enrollment among STEM majors

\begin{tabular}{lrl}
\hline & Sobel's statistic & $p$-value \\
Ethnicity (Ref. gp: white) & & \\
black & 4.7512 & $0.0000 * * *$ \\
Hispanic & 3.3389 & $0.0008 * * *$ \\
Asian & -1.7625 & $0.0780 \cdot$ \\
other & 1.4904 & 0.1361 \\
Gender (Ref. gp: male) & & \\
female & -2.9320 & $0.0034 * *$ \\
$\cdot p<0.10, * p<0.05, * * p<0.01, * * * p<0.001$ & \\
Source: U.S. Department of Education, National Center for Education Statistics, 2007-08 National \\
Postsecondary Student Aid Study (NPSAS:08).
\end{tabular}


Table 8 Logistic Regression Models of Online Course Enrollment for STEM Majors with Non-Traditional Risk Factors Shown Separately (Odds Ratios [OR] Reported, Standard Errors in Parentheses)

\begin{tabular}{|c|c|c|}
\hline & base models $^{a}$ & full model $^{b}$ \\
\hline \multirow{2}{*}{ delay. enroll. } & $1.73 * * *$ & 0.97 \\
\hline & $(0.22)$ & (0.09) \\
\hline \multirow[t]{2}{*}{ no HS dipl. } & $1.53 * *$ & 1.002 \\
\hline & $(0.44)$ & $(0.15)$ \\
\hline \multirow[t]{2}{*}{ PT enroll. } & $1.86 * * *$ & 1.08 \\
\hline & $(0.23)$ & $(0.09)$ \\
\hline \multirow[t]{2}{*}{ have depend. } & $2.31 * * *$ & \\
\hline & $(0.36)$ & \\
\hline \multirow[t]{2}{*}{ child under 6} & $2.32 * * *$ & \\
\hline & $(0.40)$ & \\
\hline \multirow[t]{2}{*}{ child under 2} & $2.41 * * *$ & $1.44 *$ \\
\hline & $(0.66)$ & $(0.24)$ \\
\hline \multirow[t]{2}{*}{ single parent } & $1.94 * * *$ & \\
\hline & $(0.39)$ & \\
\hline \multirow[t]{2}{*}{ working FT } & $2.35 * * *$ & $1.49 * * *$ \\
\hline & $(0.32)$ & $(0.12)$ \\
\hline \multirow[t]{2}{*}{ financial independence } & $2.71 * * *$ & \\
\hline & $(0.32)$ & \\
\hline \multirow[t]{2}{*}{24 or above } & $2.68 * * *$ & $1.80 * * *$ \\
\hline & $(0.32)$ & $(0.19)$ \\
\hline \multirow[t]{2}{*}{ married } & $2.40 * * *$ & 1.22 . \\
\hline & $(0.36)$ & $(0.13)$ \\
\hline \multicolumn{3}{|c|}{ military type (Ref. gp: None or reserves) } \\
\hline \multirow[t]{2}{*}{ active duty } & $6.55 * * *$ & $3.62 * * *$ \\
\hline & $(3.45)$ & $(1.02)$ \\
\hline \multirow[t]{2}{*}{ veteran } & $1.78 * * *$ & 0.91 \\
\hline & $(0.50)$ & $(0.15)$ \\
\hline \multirow[t]{2}{*}{ orphan or ward of court } & 0.55 & \\
\hline & $(0.41)$ & \\
\hline \multirow[t]{2}{*}{ remedial course-taking } & & $1.42 * * *$ \\
\hline & & $(0.09)$ \\
\hline coarsened $N^{c}$ & 27,800 & 26,700 \\
\hline pseudo $R^{2}$ (Nagelkerke) & & 0.0960 \\
\hline $\mathrm{AIC}$ & & $3,354,303$ \\
\hline$p$ (Wald F) & & $0.0000 * * *$ \\
\hline
\end{tabular}

${ }^{a}$ Each base model includes only one independent variable. For each base model, only the odds ratio for the single independent variable is reported for the sake of brevity.

${ }^{b}$ Based on Table 6 . Model coefficients for all other factors were substantially similar to those in the full model in Table 6, and for the sake of brevity have been excluded here.

${ }^{c}$ Per NCES Standards, the true sample size has been modified to minimize disclosure risk of individual survey responses.

Notes: Standard errors are in parentheses. Variance estimation was computed using Balanced Repeated Replication with 200 replicates. The weight variable used in this table is WTA000. 
Variables with grey backgrounds are those factors that were retained in the most parsimonious model (obtained via backward elimination with a threshold of 0.10). Ethnicity/gender was also retained. Source: U.S. Department of Education, National Center for Education Statistics, 2007-08 National Postsecondary Student Aid Study (NPSAS:08).

Table 9 Presence of dependents and age as mediators of G.P.A. for online enrollment among STEM majors

Sobel's statistic $p$-value

G.P.A.

Mediated by having dependants (Ref. gp: have dependents)

3.3641

0.0008

Mediated by age (Ref. gp: 24 or older)

4.5699

0.0000

$\cdot p<0.10, * p<0.05, * * p<0.01, * * * p<0.001$

Source: U.S. Department of Education, National Center for Education Statistics, 2007-08 National

Postsecondary Student Aid Study (NPSAS:08). 
Figure 1 Predicted Probability of STEM Majors taking an online course by number of nontraditional risk factors (based on Table 6, for reference group)

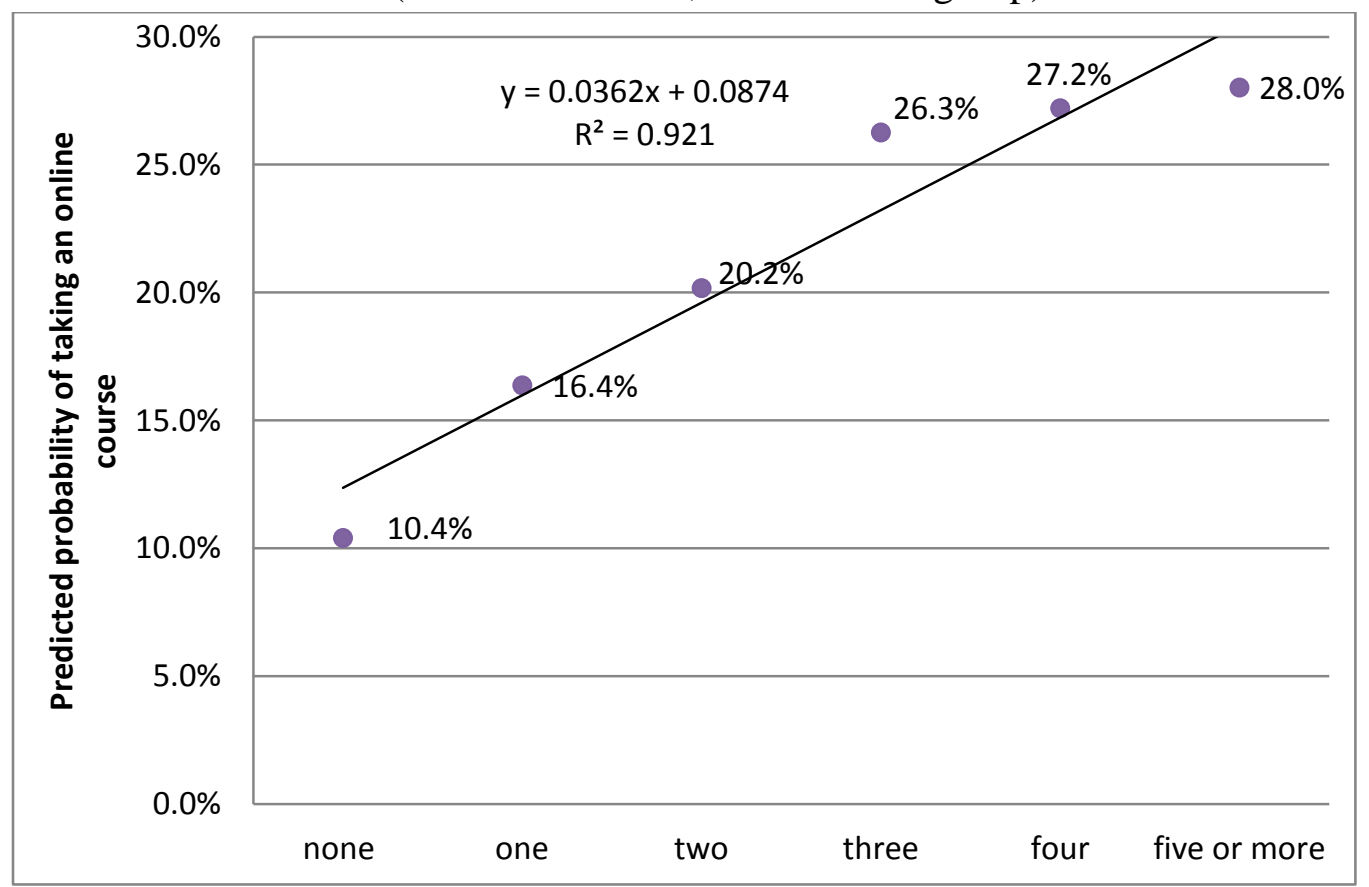


Figure 2 Predicted Probability of a STEM major taking an online course (based on Table 6) by ethnicity, gender, \& number of non-traditional risk factors

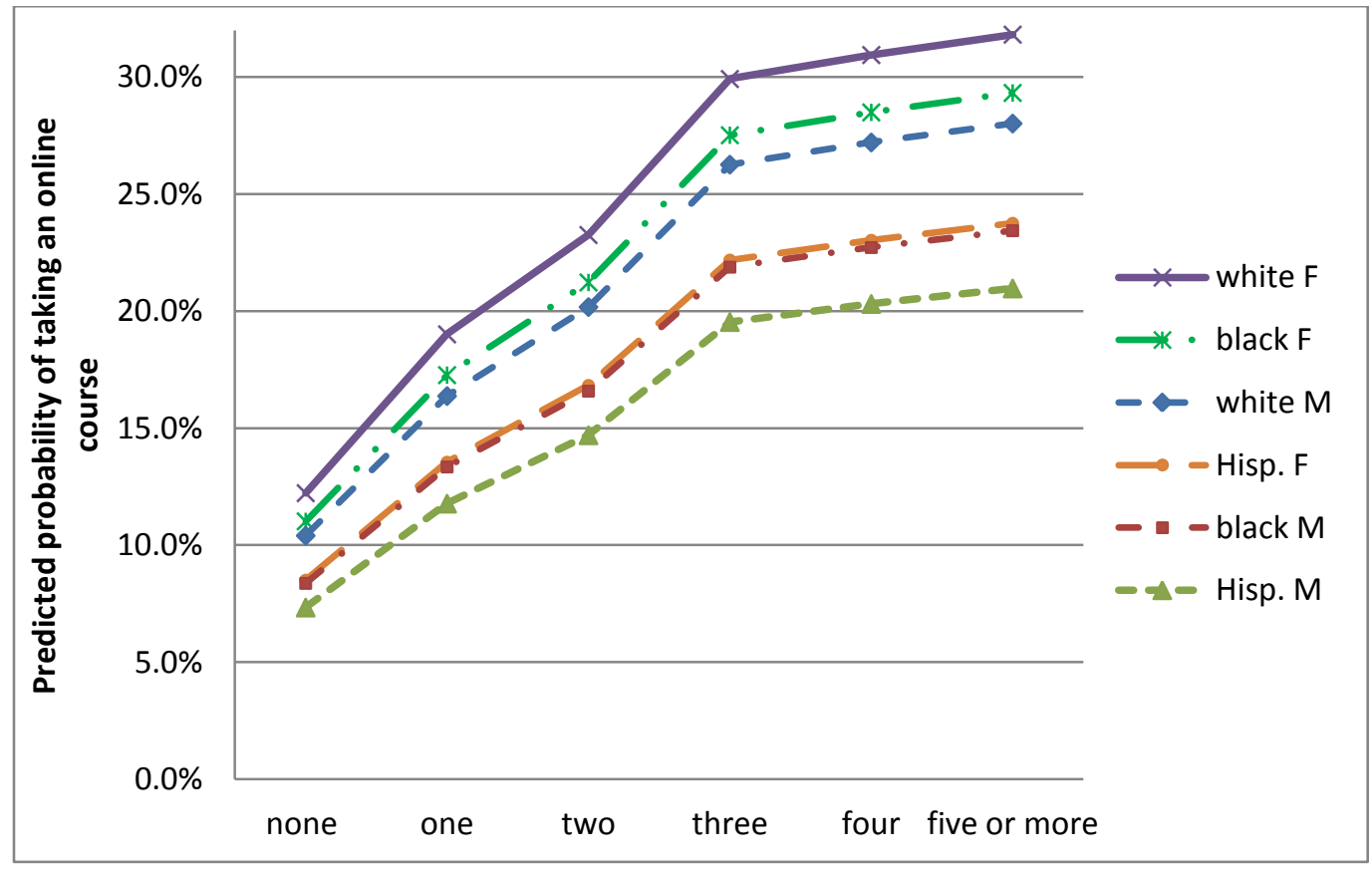


Figure 3 Predicted Probability of STEM Majors taking an online course by groups of specific non-traditional risk factors (based on Table 8, for reference group)

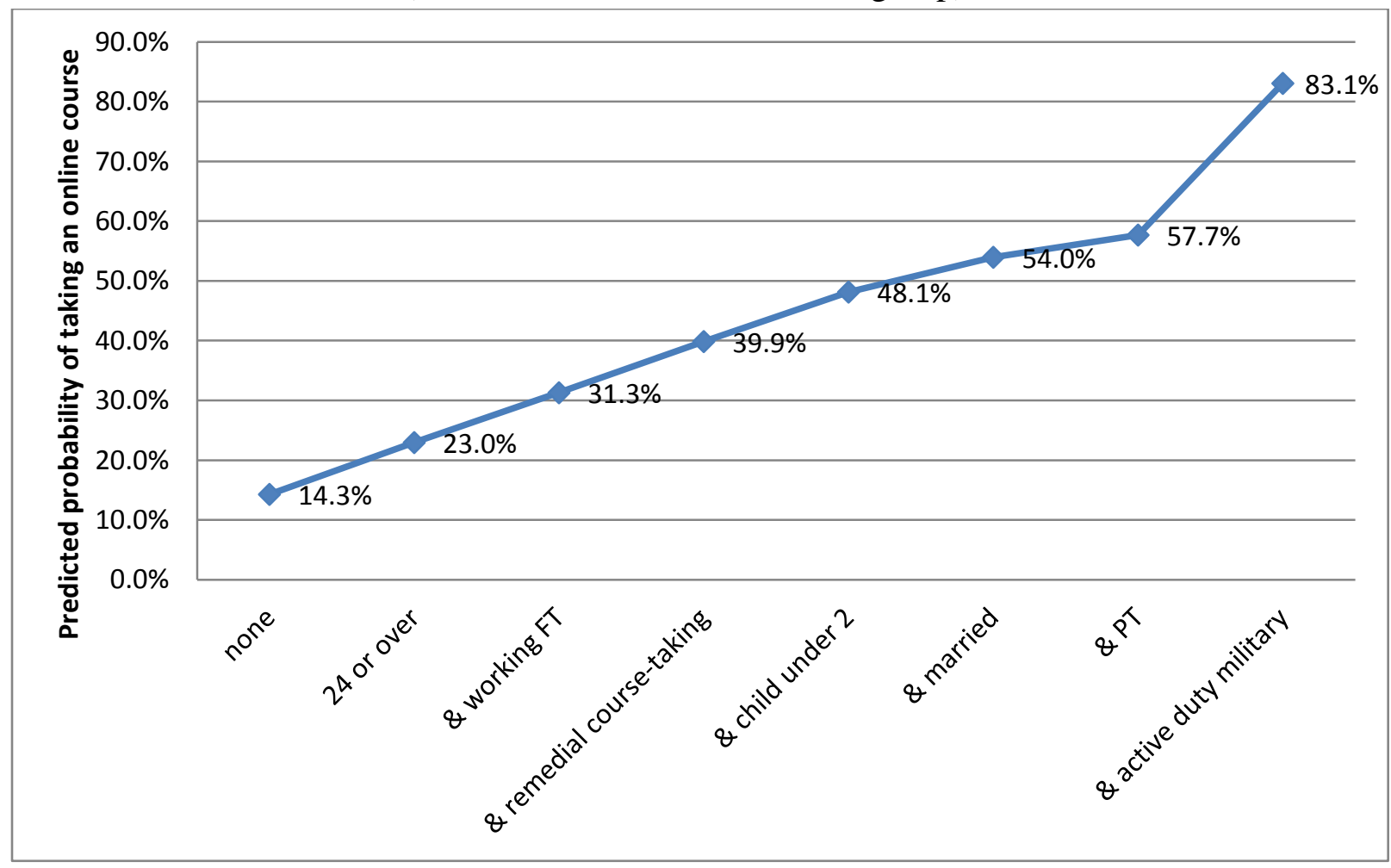




\section{ACKNOWLEDGEMENTS}

This research was supported by a grant from the American Educational Research Association which receives funds for its "AERA Grants Program" from the National Science Foundation under NSF Grant \#DRL-0941014. Opinions reflect those of the author(s) and do not necessarily reflect those of the granting agencies. 